\title{
Systematic Conservation Assessment for Most of the Colombian Territory as a Strategy for Effective Biodiversity Conservation
}

\author{
Marcela Portocarrero-Aya*, Germán Corzo, Angélica Diaz-Pulido, \\ María Fernanda González, Magnolia Longo, Lina Mesa, Andrea Paz, \\ Wilson Ramírez, Olga Lucía Hernández-Manrique \\ Alexander von Humboldt Institute for Research on Biological Resources, Bogotá, Colombia \\ Email: "mportocarrero@humboldt.org.co
}

Received 22 September 2014; revised 3 November 2014; accepted 26 November 2014

Copyright (C) 2014 by authors and Scientific Research Publishing Inc.

This work is licensed under the Creative Commons Attribution International License (CC BY). http://creativecommons.org/licenses/by/4.0/

\section{(c) (i) Open Access}

\begin{abstract}
Colombian ecosystems maintain key ecological processes that support thousands of species, including human beings. With the expansion of the country's population, and the implementation of a government's development plan based on an economy centred on extraction patterns, the conservation of these ecosystems is at serious risk. It is a priority to implement effective strategies that ensure the protection of the country's biological diversity as well as the mitigation and prevention of threats and to contribute to its proper use. Colombia's development strategies as well as its peoples' wellbeing depend on the suitable condition of its natural assets. The identification of surrogates of conservation, the formulation of conservation goals, the prioritization of key areas and the formulation of conservation strategies based on the preservation, restoration and sustainable use of the territory and its biodiversity are proposed for $60 \%$ of the emerged land $(\sim$ $700,000 \mathrm{Km}^{2}$ ). This research aims at giving proper guidelines to manage the territory and finding common points between development and biodiversity conservation, as well as to use this input for the development and implementation of a National Decision-making Support System (DSS) that will potentially have an impact on Colombia's environmental policies and territorial planning schemes.
\end{abstract}

\section{Keywords}

Decision-Making Support System, Key Areas for Conservation, Biodiversity, Colombia, Sustainable Development

\footnotetext{
${ }^{*}$ Corresponding author.
}

How to cite this paper: Portocarrero-Aya, M., et al. (2014) Systematic Conservation Assessment for Most of the Colombian Territory as a Strategy for Effective Biodiversity Conservation. Natural Resources, 5, 981-1006. 


\section{Introduction}

In tropical ecosystems, conservation and management decisions are characterized by their complexity and uncertainty. This is a result of the dynamism of the ecosystems, the lack of knowledge regarding their structure, composition and function, and the complexity of the human communities that live and depend on the resources provided by these, and in the difficulties in valuing natural resources and ecological services, accompanied by the involvement of numerous stakeholders in the process [1]. Conservation and management decisions are also tempered by social and political conflicts in countries with poverty, insecure land tenure, unstable political systems, and other social and political issues [2].

Colombian ecosystems are not an exception in complexity and as a mega diverse country it is responsible for the proper use of threatened ecosystems and species, of those considered unique among others in the world, and the ones providing goods and services vital for its people. According to the latest National Development Plan 2010-2014 [3], Colombia aims to reach prosperity through the development of five main engines: agriculture, infrastructure, housing, innovation, and mining and energy. All these are part of an economic development strategy that constitutes, sadly, the main foundation for Colombia's population wellbeing [4]. For decades, the country's natural resources have been used and exploited to generate prosperity and have contributed enormously to improve the wellbeing and income of a large part of its population. However this success has been accompanied by an environmental deterioration and issues like logging, biodiversity loss, and water and air pollution have been accentuated [1] [5]-[9]. The expansion in the demand for food, for traditional fuels and biofuels is increasing, and with it the pressure for land conversion and in many places the enhancement of poverty [10]. Maintaining healthy ecosystems and ecological processes is vital for the proper functioning of any economy and it must be acknowledged by national authorities who keep pushing national and regional development actions without understanding the direct connection among the natural capital, people's welfare and the country's development [11] [12].

In Colombia, approximately $40 \%$ to $60 \%$ of the land area remains in natural conditions while the remaining has been heavily transformed by human activities [5] [6] [9]. Part of this remnant naturalness, is due to the presence of Indigenous and Afro-descendant Territories that cover $\sim 30 \%$ of the emerged land [13], accompanied by a comprehensive network of 58 Protected Areas that cover $11.38 \%$ of the emerged land and $1.48 \%$ of the marine area. However, recent publications have shown important changes in the forest cover, forecasting on-going and alarming scenarios for the country's biodiversity [5] [6] [9].

Currently new challenges have been set up regarding biodiversity conservation. These challenges must deal with a heterogeneous country with a growing economy based on the extraction of its natural resources, a rich but poorly known biological and cultural diversity, social unbalance and noticeable gaps in the information needed by decision makers. So conserving what already is protected by law and effective planning of the territory and its components constitute the key and essential ways of overcoming part of these challenges for the national and regional environmental authorities, research institutes and the civil society, as well as for the Ministries of Energy, Development, Agriculture, Housing and Infrastructure [3] [4].

Activities such as mineral and oil exploration and extraction (almost 200,000 $\mathrm{Km}^{2}$ have been allocated for mining prospecting) [5], agriculture and ranching (with the use of technologically intensive systems), and the generation of hydropower (through the construction of dams) are big threats to the country's natural assets. These risks are enhanced by the lack of law enforcement and political will, as well as a current demand for goods and services leading to changes in the consumption patterns of the country's inhabitants [3] [13]. It is also important to take into account that currently Colombia's peace talks between the Government and the FARC (Revolutionary Armed Forces of Colombia, People's Army—an irregular military organization) considers a post conflict scenario based on the enhancement and improvement of the agriculture, the rural peoples conditions and the restitution of the territory for productive activities. If this is done without considering the carrying capacity of the land, its ecological structure and network, the availability of water resources, and the connectivity and integrity of natural and undisturbed ecosystems, ecological conflicts could occur and therefore socio-economic conflicts too.

Threats have been identified but little is known regarding their impacts on the territory and its biodiversity, and even less information is available regarding the vulnerability of the land and its natural features. Information regarding these issues is crucial for effective conservation planning [14]-[17]. For this reason it is very important to have a way of establishing conservation goals that will try to secure parts of the territory for the implementation of conservation and management strategies. 
The latest National Report on Biodiversity [18] stated how urgent it is to formulate and implement holistic, integral and systematic conservation strategies to stop this on-going deterioration, which is now noticeable with phenomena such El Niño and La Niña, costing the country and its people money and wellbeing. The formulation of integrated conservation initiatives and their implementation in an accurate way is urgent. The renewed and adaptive methodologies need to be used according to specific objectives, realities, and needs, while integrating conservation strategies (preservation, restoration, sustainable use, and knowledge generation) into the operational and development plans of the sectors and the government.

Systematic conservation assessments are key to have a full view of the territory and its components and making the formulation and implementation of territorial planning-strategies less random [19]-[27]. According to Sakar et al. [27], "systematic conservation planning is a dynamic process in which prioritization tools aid decision makers in identifying good policy options". A good number of these tools have been standardize to suit different countries, regions and objectives within prioritization exercises in places like Africa [21], Australia [24]-[26], Europe [28] and North America [20] [29] [30] where good and reliable information on biodiversity is available. In tropical regions biodiversity knowledge is still quite poor and prioritization tools need to be adapted and modified according to objectives, areas and available information [13] [28].

Systematic conservation includes a series of complementary strategies that all together aim at giving solution to environmental conflicts that lead to social conflicts caused mainly by an existing economic inequality (Colombian GINI Index: 55.9) [31]. The prioritization of key areas for conservation and the identification of species as surrogates of conservation have become one of the most accepted strategies among conservationists and local inhabitants [32]-[36], as well as proper tools within systematic territorial planning. Many different approaches can be used to identify key areas, and numerous tools for their identification have been developed [13] [24] [25] [27] [29] [32] [36].

The identification of surrogates of conservation has been useful, especially in countries with rich biodiversity. The representation of a full variety of biodiversity within a single species or a group of them has proved effective in ecosystem-based conservation strategies. Conservation surrogates are also useful in the identification of areas of high environmental value and in areas proposed for special protection (National Parks, Reserves, Freshwater Protected Areas and so on). This strategy is useful in Colombia, where the understanding of the species, their habitats and dynamics is poor. The Colombian conservation goals set in the National Policy for the Integral Management of Biodiversity and its Ecosystem Services (PNGIBSE) aim to identify these elements of biodiversity and establish strategies that can prevent their disappearance [5].

Colombia counts with approximately 33 portfolios of key conservation areas [37]-[39] all providing different conclusions and recommendations on how to manage particular conservation objects and/or their territory. These have been made with different methodologies, study areas, scales, conservation goals, and objectives, making their unification into a single portfolio that could show priority areas at a national scale very difficult. Most of the portfolios for priority areas end up giving a map of ones and zeros, priority and non-priority areas, imparting the idea that the non-priority areas are subject to be used without discrimination. Conservation strategies or guidelines are needed for both priority and complementary [non-priority] areas to establish proper territorial management proposals that might be useful and common to both conservationist and developers, closing the existing gap between them.

An initial step to the identification of key areas should be the formulation of conservation goals. These goals will help to understand which proportion of the territory is fundamental and vital for the maintenance of ecological processes, the species and their assemblages. Conservation goals will be accomplished with the best areas of the territory, those with the highest levels of naturalness, connectivity, integrity, provision of ecosystem services and other characteristics that will help to organize the territory making easier the implementation of territorial planning and conservation schemes, according to an adequate balance between the offer and social demand of ecosystem services [40] [41].

In Colombia, so far there has not been a single initiative where the development sector and the environmental stakeholders participate at a large scale trying to combine elements from both sides. For this reason the Humboldt Institute (part of the National Environmental System and the party responsible for carrying out scientific research on biodiversity, as well as providing information for decision makers to ensure the integral management of the country's biodiversity and its associated ecological services) and Ecopetrol (the largest oil company in the country) joined forces to formulate conservation strategies, guidelines and projects in the $60 \%$ of emerged territory in prioritized and complementary areas for biodiversity conservation. This part of the territory corres- 
ponds to the area of influence of the company and the results aim at leading territorial planning programs as well as addressing the implementation of activities to avoid and mitigate threats to the biodiversity. These activities will be complemented by voluntary and obligatory compensation schemes aiming at the no net loss of biodiversity and even at its improvement as part of the company's corporate's social and environmental responsibility.

The manuscript presented here seeks to answer a basic set of questions regarding biodiversity conservation in Colombia: What to conserve? (Surrogates of conservation-coarse and fine filter targets); How much to conserve? (Conservation goals); Where to conserve? (Identification of priority and complementary areas); and How to conserve? (Formulation of conservation strategies according to the involved actors and their jurisdiction). All these represent complementary conservation actions as part of a systematic conservation planning strategy aiming at becoming the inputs of a National Decision-making Support System [DSS].

\section{Materials and Methods}

\subsection{Study Area}

The area comprises $703,726 \mathrm{Km}^{2}$ (60\% of the emerged territory) corresponding to the regions of the Caribbean $\left(139,298 \mathrm{Km}^{2}\right)$, Pacific $\left(118,955 \mathrm{Km}^{2}\right)$, Andes and Amazon piedmont $\left(255,288 \mathrm{Km}^{2}\right)$, and part of the Orinoquia $\left(190,185 \mathrm{Km}^{2}\right)$ (Figure 1).

\subsection{Territorial Analysis Units (AU) (What to Conserve?)}

The formulation of Territorial Analysis Units is the result of an integration of hydro-biological and biogeography features incorporated into three thematic maps generated exclusively for this project at a scale of 1:100,000: Hydro-biographic Zones, Biogeographic Districts and Biomes. The integration of the three layers here constitutes our Coarse Filter Targets. All AUs are homogeneous within and heterogeneous among them, intending to incorporate a high biological content with a historic and current view from a terrestrial and aquatic perspective. The AUs located in the Páramo ecosystem were identified using the Atlas of Páramo [42]. They were chosen as single AUs due to their ecological singularity and the representativeness of their biodiversity in the territory [42] and therefore their composition differs from the others.

Conservation Surrogates (What to conserve?)

Based on the literature review and the methodologies for the identification of fine filter targets (FFT) proposed by WWF, CI and TNC [43]-[47], a series of species of flora and fauna were chosen as candidates to be surrogates of conservation.

A list of all terrestrial and aquatic plants and all vertebrate species registered in the study area was compiled. The information for each clade came from published papers, grey literature, red books of endangered species, collections and world data bases. The long list highlighted the impracticality of trying to protect every single element and the importance of identifying a few species to be used as conservation surrogates that represent the high number of species reported for the study area.

The criteria and sub-criteria established to identify fine filter targets (species) (Table 1) [44]-[46] [48] [49] was ranked from 1 to 5 (being 1 the lowest and 5 the highest) and then the following algorithm (Equations (1), (2), (3)) was applied to prioritize those species with the best features to qualify as candidates to be surrogates of conservation.

$$
\begin{aligned}
& \text { Plants FFT }=[(0.2 * \mathrm{IUCN}+0.6 * \mathrm{NRL}+\text { does not apply } * \mathrm{LL}+0.2 * \text { CITES })+(0.7 * \text { endemism }+0.3 * \text { use })] \\
& \text { Fishes FFT }=\left[\begin{array}{l}
(0.2 * \text { IUCN }+0.55 * \mathrm{NRL}+0.25 * \mathrm{LL})+(0.6 * \text { ecological function }+0.4 * \text { habitat dependency }) \\
+(0.35 * \text { endemism }+0.15 * \text { migrant }+0.15 \text { special features }+0.35 * \text { use })
\end{array}\right] \\
& \text { Vertebrates (fishless) FFT }=\left[\begin{array}{l}
(0.2 * \text { IUCN }+0.6 * \text { NRL }+0.2 * \text { CITES }) \\
+(0.6 * \text { ecological function }+0.4 * \text { habitat dependency }) \\
+(0.35 * \text { endemism }+0.15 * \text { migrant }+0.15 \text { special features }+0.35 * \text { use })
\end{array}\right]
\end{aligned}
$$

After this first filter, the resultant species were reassessed by a group of experts whom ranked them again based on the threats and the vulnerabilities of each species. The final qualification helped in the identification of the final surrogates of conservation for each taxonomic group. 


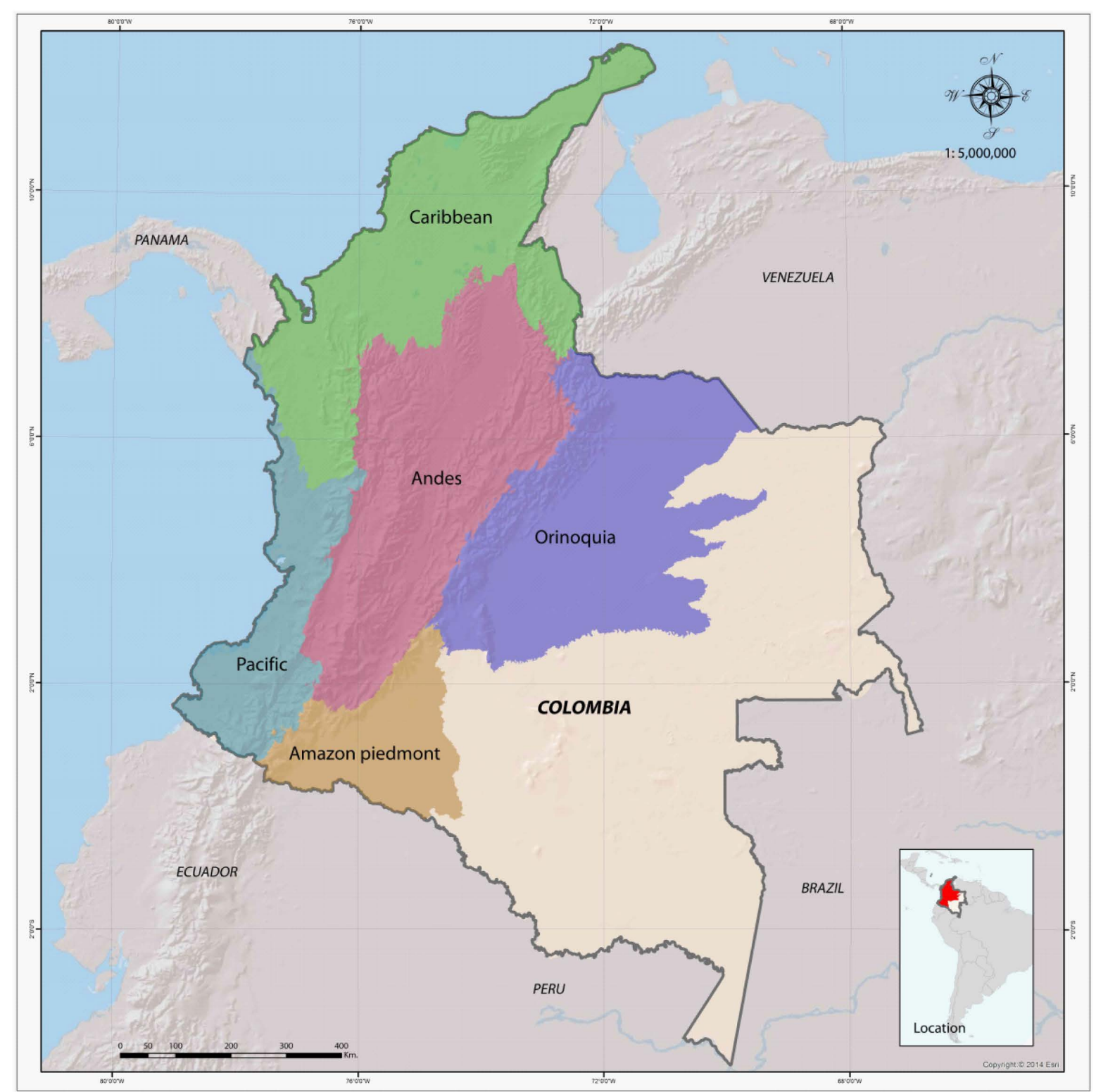

Figure 1. Study area—Caribbean, Pacific, Andean, Amazon (piedmont) and Orinoquia Regions, Colombia.

\subsection{Conservation Goals Calculation (CG) (How Much to Conserve?)}

Conservation goals for each Unit of Analysis were obtained from the unified index of probability of collapse of biodiversity [50]. This index was constructed on the basis of threats and vulnerabilities and the interaction amongst them, considering different levels of threats and therefore different levels of impact on each one of the AUs according to each one of their vulnerabilities. Two separate indexes were conducted for terrestrial and aquatic realms, their data normalized, and then unified into a single scoring.

Conservation goals were set between $17 \%$ and $60 \%$. According to the Convention on Biological Diversity, Goal 11 of the Strategic Plan for Biodiversity 2011-2020 states: "by 2020 at least $17 \%$ of the terrestrial and freshwater territory should be managed efficiently and in a equitably way, as well as to be ecologically representative" [51]. That idea was taken and considered accurate to set the minimum goal for each AU at $17 \%$. The maximum was based on some authors [17] [52] [53] that have considered and demonstrated that changes superior to the $40 \%$ in the original condition of the territory can cause the loss of homeostasis of the ecosystems. Minimum values of risk are associated to minimum conservation goals and vice-versa. 
Using data from the index of probability of collapse of biodiversity, the maximums and minimums percentage values $(0.33 ; 100)$ [50] were associated to the minimum (17) and maximum (60) conservation goals. The values were plotted (Conservation Goals vs. probability of collapse) looking for the best relationship (linear, exponential or potential) between them. A third point $(3.65,30)$ was used to give more certainty to the graph. The probability of collapse value of 3.65 corresponds to the Mode value of the data, and the $30 \%$ of CG to what Odum (1989) [37] stated regarding an ideal 30\% to conserve the functionality of any territory (with the exception of ecosystems with special spatial distribution such as Tropical Dry Forest, Mangroves and Páramos) (Figure 2). With the final formulae, the conservation goals values were obtained.

Potential Function Formulae: $\mathrm{Y}=22.02\left(\mathrm{X}^{0.2199}\right)$;

$\mathrm{Y}=$ Conservation goal (\%);

$\mathrm{X}=$ Probability of collapse (\%).

\subsection{Prioritization of Key Areas: (Where to Conserve?)}

The areas were prioritized using a decision tree as a prioritization tool. Twenty-nine (29) variables were used following the order presented in the Table 2 . These variables or fields were applied one after the other, resulting

Table 1. Criteria for the selection of conservation surrogates (fine filter targets).

\begin{tabular}{|c|c|c|}
\hline Criteria & Sub-criteria & Categories and ranks \\
\hline \multirow{4}{*}{$\begin{array}{l}\text { 1. Status of conservation at a global, } \\
\text { national or local level }\end{array}$} & IUCN red list & CR (5) EN (4) VU (3) DD (3) LC (1) NT (2) \\
\hline & National red lists—NRL & CR (5) EN (4) VU (3) DD (3) LC (1) NT (2) \\
\hline & Local lists_LL & Yes (5) Not (0) \\
\hline & CITES (except for fish) & CITES Appendix I (5), II (3) and III (3) \\
\hline \multirow{2}{*}{$\begin{array}{l}\text { 2. Species with a visible ecological } \\
\text { function, specific habitat user (only } \\
\text { for fauna) })^{\dagger}\end{array}$} & Ecological importance & $\begin{array}{l}\text { Carnivore (5), herbivore (5), seed disperser (5), } \\
\text { pollinator (5), insectivore (5), bio indicator (5), algae } \\
\text { feeder (5), omnivore (1). }\end{array}$ \\
\hline & Habitat dependency & $\begin{array}{l}\text { Very specialist (5), specialist (3), minor specialist } \\
\text { (2), non-specialist (1). }\end{array}$ \\
\hline \multirow{4}{*}{$\begin{array}{l}\text { 3. Species of cultural and/or mythical } \\
\text { importance; species of } \\
\text { socio-economic importance; and } \\
\text { species representing special features }\end{array}$} & Endemism (only for fauna) & $\begin{array}{l}\text { Endemic very restricted (5), endemic restricted (3), } \\
\text { non-endemic (1) }\end{array}$ \\
\hline & Migratority & Migrant (5) , non-migrant (1) \\
\hline & Special features & $\begin{array}{l}\text { Flagship (1), umbrella or charismatic (1), no special } \\
\text { features (0) }\end{array}$ \\
\hline & Use & with a special use (5), with no use (1) \\
\hline
\end{tabular}

${ }^{\dagger}$ Due to the little information available for terrestrial plants regarding their ecological function, this criterion was not taken into account and in the equation (Equation (1)) the value of habitat dependency was multiplied by 1.

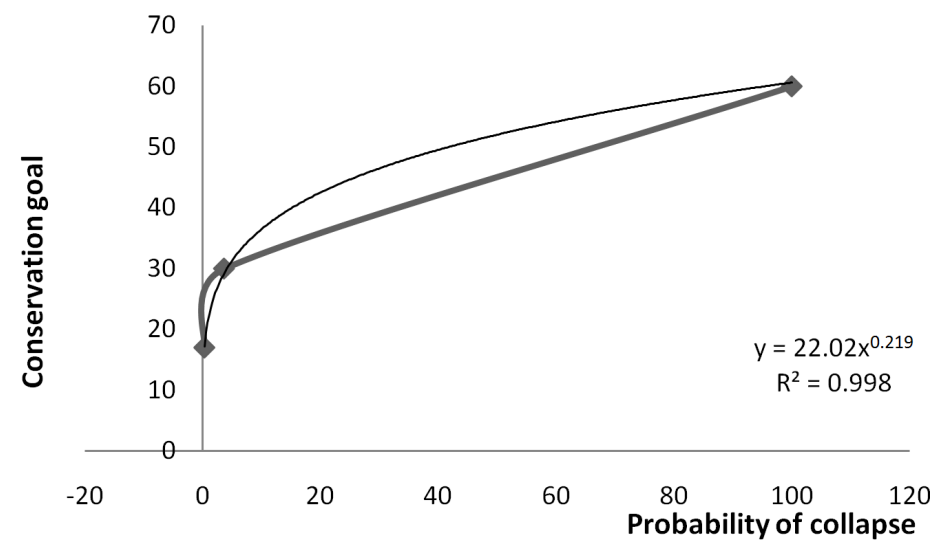

Figure 2. Potential function curve between conservation goals [\%] and the probability of collapse $\left[\mathrm{R}^{2}=0.9989\right]$. 
Table 2. Variables and categories used to build the decision tree.

\begin{tabular}{|c|c|c|}
\hline Variables & Classification & Source/Scale \\
\hline \multirow{7}{*}{$\begin{array}{l}\text { 1. National Protected Areas } \\
\text { System }\end{array}$} & National Natural Parks & \\
\hline & Regional Natural Parks & \\
\hline & National or Regional Protective Forest Reserves & \\
\hline & Regional Districts of Integrated Management & $\begin{array}{l}\text { National Natural Parks Unit of } \\
\text { Colombia }(1: 100,000)\end{array}$ \\
\hline & Soil Conservation Districts & \\
\hline & Recreation Areas & \\
\hline & Natural Reserves of the Civil Society & \\
\hline \multirow{2}{*}{ 2. Forest Reserves } & $\begin{array}{l}\text { Type A (Law } 2 \text { of 1959-Resolutions } 1922 \text { to } \\
1926 \text { from the 27th of December 2013) }\end{array}$ & $\operatorname{IGAC}^{*}(1: 1,500,000)$ \\
\hline & Protective Forest Reserves (Decrete 2278 of 1953) & $\begin{array}{l}\text { Humboldt Institute }(1: 100,000) \\
\text { (created for this research) }\end{array}$ \\
\hline \multirow{5}{*}{ 3. Strategic Ecosystems } & Páramos & Humboldt Institute $(1: 100,000)$ \\
\hline & Freshwater Ecosystems & IGAC $(1: 100,000)$ \\
\hline & Ramsar Sites & IGAC $(1: 100,000)$ \\
\hline & Tropical Dry Forest & Humboldt Institute $(1: 100,000)$ \\
\hline & Mangroves & IGAC $(1: 100,000)$ \\
\hline $\begin{array}{l}\text { 4. Guidelines for the } \\
\text { Consolidation of the National } \\
\text { System of Protected Areas }\end{array}$ & $\begin{array}{l}\text { National Council for Economic and Social } \\
\text { Policy_Conpes } 3680\end{array}$ & \\
\hline $\begin{array}{l}\text { 5. Portfolio and Expansion } \\
\text { of the National Natural Parks } \\
\text { System }\end{array}$ & & $\begin{array}{l}\text { National Natural Parks Unit of } \\
\text { Colombia }(1: 100,000)\end{array}$ \\
\hline 6. Ecosystem Integrity & & $\begin{array}{l}\text { Humboldt Institute }(1: 100,000) \\
\text { (created exclusively for this } \\
\text { research) }\end{array}$ \\
\hline 7. Connectivity & & $\begin{array}{l}\text { Humboldt Institute }(1: 100,000) \\
\text { (created exclusively for this } \\
\text { research) }\end{array}$ \\
\hline \multirow{6}{*}{$\begin{array}{l}\text { 8. Opportunities for } \\
\text { Conservation }\end{array}$} & $\begin{array}{l}\text { Forest Reserves Types B and C (Law } 2 \text { of } \\
\text { 1959-Resolutions 1922 to } 1926 \text { from the } \\
\text { 27th of December 2013) }\end{array}$ & IGAC $(1: 1,500,000)$ \\
\hline & Indigenous Reserves & $\operatorname{INCODER}^{* *}(1: 250,000)$ \\
\hline & Afro-Descendent Territories & \\
\hline & Farmers Reserves & \\
\hline & Prioritized Areas According to Former Portfolios & $\begin{array}{l}\text { National Natural Parks Unit of } \\
\text { Colombia }(1: 100,000)\end{array}$ \\
\hline & $\begin{array}{l}\text { Complementary Mechanisms for the Conservation of } \\
\text { Biodiversity (Protected Areas Not Included } \\
\text { in the National Protected Areas System) }\end{array}$ & $\begin{array}{l}\text { Conservation International } \\
\text { Colombia }\end{array}$ \\
\hline \multirow{3}{*}{ 9. Ecosystem Services } & Water Regulation & $\operatorname{IDEAM}^{* * *}(1: 100,000)$ \\
\hline & Carbon Storage & IDEAM $(1: 100,000)$ \\
\hline & Biodiversity & Humboldt Institute $(1 \mathrm{Km} \times 1 \mathrm{Km})$ \\
\hline $\begin{array}{l}\text { 10. Prioritized Basins for } \\
\text { Clime Change Adaptation }\end{array}$ & Prioritized Basins & Humboldt Institute $(1: 100,000)$ \\
\hline
\end{tabular}




\section{Continued}

11. Land Cover Classification 2007

\author{
1. Artificialized Territories \\ 1. Urban Network \\ 2. Agricultural Areas \\ 2.1. Arable Land \\ 2.2. Permanent Crops \\ 2.3. Pastures \\ 3. Semi-Natural Areas \\ 2.4. Heterogeneous Agricultural Areas \\ 3.1.3. Fragmented Forest \\ 3.2.3. Secondary or Transitional Vegetation \\ 4. Natural Areas \\ 3.1.1. Broad Level Forest \\ 3.1.2. Open Forest \\ 3.1.4. Riparian Forest \\ 3.1.5. Forestry Plantation \\ 3.2.1.1. Natural Grasslands \\ 3.2.2.2. Moors and Heathland \\ 3.3.1. Beaches, Dunes, Sands \\ 3.3.2. Bare Rocks \\ 3..33. Sparsely Vegetated Areas \\ 3.3.4. Burnt Areas \\ 3.3.5. Glaciers and Perpetual Snow \\ 5. Wetlands
}

$\operatorname{IDEAM}(1: 100,000)$ ${ }^{*}$ Geographic Institute Agustin Codazzi; ${ }^{* *}$ Colombian Institute for Rural Development; ${ }^{* * *}$ Colombian Institute of Hydrology, Meteorology and Envi-
ronmental Studies.

in a hierarchy of branches within branches that produced the characteristic decision tree form. Each branch of the tree leads to a selection of pixels $(30 \mathrm{~m} \times 30 \mathrm{~m})$ starting with those already under legal conditions (PAs, Forest Reserves, Strategic Ecosystems) and then those pixels reaching the best conditions (high connectivity, high integrity, etc.) to the ones with less number of conditions. The selection of pixels stopped the moment the conservation goal per UA was reached.

\subsection{Management Strategies (How to Conserve?)}

Three main strategies were defined for the prioritized areas (preservation, restoration and sustainable use). They were classified according to the characterization that all variables summed together gave to each pixel (Table 3). Land cover, legal status, functionality and integrity were the main characteristics to classify.

Given that the conservation planning proposal is systematic and integrated and looking for the complementarity with the prioritized areas, alternative conservation guidelines were given to the non-prioritized (complementary) areas.

\section{Results}

\subsection{Terrestrial Analysis Units (AU) (What to Conserve?)}

A total of 268 AU's resulted, from which 51 are in the Caribbean, 46 in the Pacific, 141 in the Andes, 14 in the Amazon piedmont and 16 in the Orinoquia region (Figure 3). 
Table 3. Conservation strategies for the priority areas within $60 \%$ of the Colombian emerged territory.

\begin{tabular}{|cl}
\hline Strategies and guidelines & \multicolumn{1}{c}{ Explanation } \\
\hline Preservation & $\begin{array}{l}\text { Natural areas }{ }^{*} \text { in priority areas (Protected areas, strategic ecosystems, indigenous and } \\
\text { afro-descendant territories, areas with high integrity and connectivity, ecosystem services, etc.). }\end{array}$ \\
Restoration & $\begin{array}{l}\text { Semi-natural and transformed areas } \\
\text { protected areas, strategic ecosystems, and areas of high importance } \\
\text { (CONPES, Indigenous and Afro-descendant Territories, etc.). }\end{array}$ \\
Sustainable use & $\begin{array}{l}\text { Transformed }{ }^{*} \text { areas. The best possible pixels to achieve the conservation goal per AU with minor } \\
\text { connectivity, integrity, opportunities of conservation and ecosystem services. }\end{array}$ \\
\hline
\end{tabular}

${ }^{*}$ According to the land cover classification.

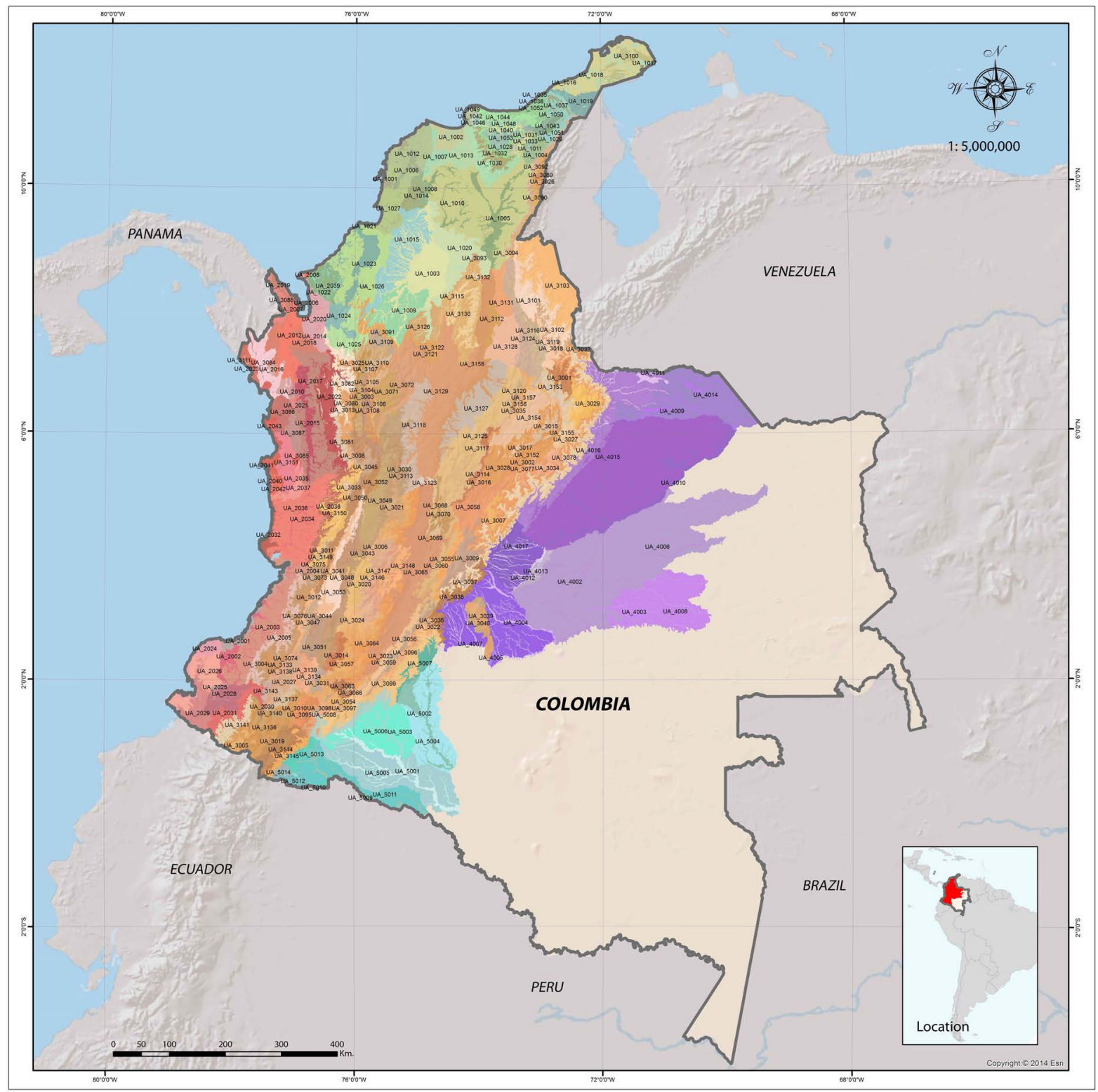

Figure 3. Map of territorial analysis units (extended legend Appendix).

\section{Conservation surrogates (Fine Filter Targets) (What to conserve?)}


The identification of conservation surrogates is considered a complementary strategy to the identification of AUs, the conservation goals calculation (CG) as well as the identification of key areas and the generation of strategies for their conservation (Table 4).

\subsection{Conservation Goals Calculation (CG) (How Much to Conserve?)}

Unified probability of collapse values ranked from 0.50 to 151 , corresponding to percentage values from $0.33 \%$ to $100 \%$ [50]. A minimum conservation goal set at $17 \%$ was given to the minimum percentage value of collapse and the maximum conservation goal of $60 \%$ was given to the maximum percentage of collapse. The maximum conservation goal of $60 \%$ was given to the AU (3058) Orobiome with Andean and high Andean forest on the western slope of the Eastern Cordillera located in the Andes region (Figure 3, Appendix). Average results per region show that both the Andes and Caribbean regions have the highest values and the Pacific and Amazonia piedmont exhibit the lowest. This is a result of the levels of naturalness in the regions. Additionally, the Andes and the Caribbean have, for centuries, been exposed to high impacts due to anthropogenic activities. It is estimated that almost $70 \%$ of the country's population is located on the Andes mountain range [6] [9] [54] [55] (Figure 4, Figure 5).

To the Units of Analysis of Páramo, due to their current status, were awarded with a final conservation goal of $100 \%$. The conservation goal corresponds to the minimum area in each AU needed to fulfil biodiversity conservation requirements under actions of preservation, restoration and sustainable use. In the case of the Páramo Units, the legislation considers them strategic ecosystems therefore their entire area must be under conservation strategies, the same as preservation.

Table 4. The most relevant species as surrogates of conservation per taxonomic group.

\begin{tabular}{|c|c|c|c|}
\hline $\begin{array}{l}\text { Taxonomic } \\
\text { group }\end{array}$ & $\begin{array}{l}\text { Number of species } \\
\text { compiled }\end{array}$ & $\begin{array}{c}\text { Number of species after first } \\
\text { prioritization }\end{array}$ & $\begin{array}{l}\text { Number of species after } \\
\text { experts opinion }\end{array}$ \\
\hline \multirow{3}{*}{ Plants } & 2798 & 715 & 106 \\
\hline & \multicolumn{3}{|c|}{$\begin{array}{l}\text { Magnolia virolinensis; Aniba perutilis; Gustavia latifolia; Ceroxylon sasaimae; Cavanillesia chicamochae; } \\
\text { Espeletia paipana; Zamia encephalartoides; Aniba perutilis; Carinia napyriformis; Colombobalanus excels; } \\
\text { Caesalpinia ebano; Carinia napyriformis; Astrocaryum malybo; Magnolia katiorum; Aspidosperma polyneuron; } \\
\text { Aspidosperma megalocarpon; Reinhardtia gracillis; Reinhardtia koschnyana; Reinhardtia simplex; Zamia } \\
\text { restrepoi; Zamia disodon; Zamia muricata; Zamia melanorachis }\end{array}$} \\
\hline & 1952 & 444 & 131 \\
\hline \multirow[t]{2}{*}{ Fish } & \multicolumn{3}{|c|}{$\begin{array}{l}\text { Brachyplatystoma filamentosum; Brycon moorei; Ichthyoelephas longirostris; Prochilodus magdalenae; } \\
\text { Hypostomus hondae; Epinephelus itajara; Notarius bonillae; Seudoplatystoma magdaleniatum; Ageneiosus pardalis; } \\
\text { Panaque cochliodon; Pimelodus grosskopfii; Salminus affinis; Cyphocharaxma gdalenae; Megalops atlanticus }\end{array}$} \\
\hline & 869 & 224 & 73 \\
\hline \multirow[t]{2}{*}{ Amphibians } & \multicolumn{3}{|c|}{$\begin{array}{l}\text { Atelopus minutulus; Allobates ranoides; Centrolenea canthidiocephalum; Pristimantis savagei; } \\
\text { Pristimantis jorgevelosai; Hyloxalus ruizi; Pristimantis bernali; Pristimantis scopaeus; Pristimantis simoteriscus; } \\
\text { Colostethus thorntoni; Hyloxalus betancuri; Cryptobatrachus conditus; Cryptobatrachus ruthveni; Allobates ignotus; } \\
\text { Pristimantis insignitus; Pristimantis reclusas; Caecilia caribea; Pristimantis carmelitae }\end{array}$} \\
\hline & 601 & 158 & 36 \\
\hline \multirow[t]{2}{*}{ Reptiles } & \multicolumn{3}{|c|}{$\begin{array}{l}\text { Podocnemis lewyana; Atractus indistinctus; Boa constrictor; Eunectes murinus; Podocnemis expansa; } \\
\text { Podocnemis lewyana; Anolis menta; Anolis paravertebralis; Anolis sanctamartae; Anolis umbrivagus; } \\
\text { Anolis gaigei; Anolis solitarius }\end{array}$} \\
\hline & 2655 & 681 & 72 \\
\hline \multirow[t]{2}{*}{ Birds } & \multicolumn{3}{|c|}{$\begin{array}{l}\text { Cistothorus apolinari; Amazona festiva; Oxyura jamaicensisandina; Ognorhynchus icterotis; Ara militaris; } \\
\text { Podiceps occipitalis; Sarkidiornis melanotos; Crax alberti; Synallaxis subpudica; Rallus semiplumbeus; } \\
\text { Anas georgica; Crax alberti; Ara militaris; Myiotheretes pernix; Craxdau bentoni; Chauna chavaria }\end{array}$} \\
\hline & 770 & 194 & 73 \\
\hline Mammals & \multicolumn{3}{|c|}{$\begin{array}{l}\text { Lagothrix lugens; Ateles belzebuth; Aotus brumbacki; Myrmecophaga tridactyla; Priodontes maximus; } \\
\text { Tapirus kabomani; Tapirus pinchaque; Proechimys canicolis; Proechimys chrysaeolus; Orthogeomys thaeleri; } \\
\text { Dinomys branickii; Trichechus manatus; Atelesfus ciceps; Ateles hybridus; Saguinus oedipus; Panthera onca }\end{array}$} \\
\hline TOTAL & 9645 & 2416 & 491 \\
\hline
\end{tabular}




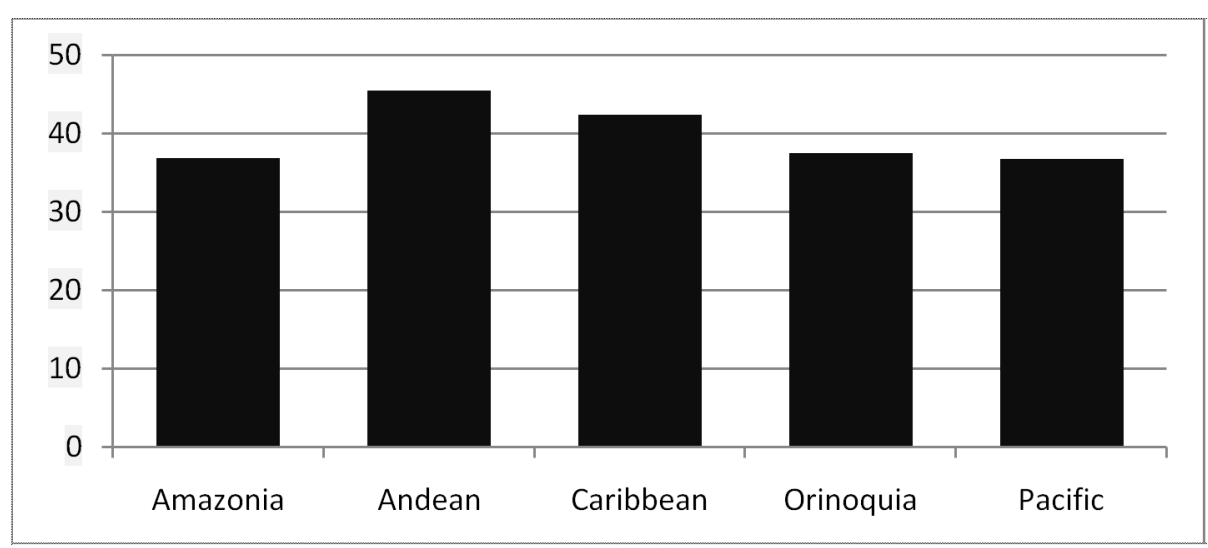

Figure 4. Average values of conservation goals for the five regions-Amazonia, Andes, Caribbean, Orinoquia and Pacific.

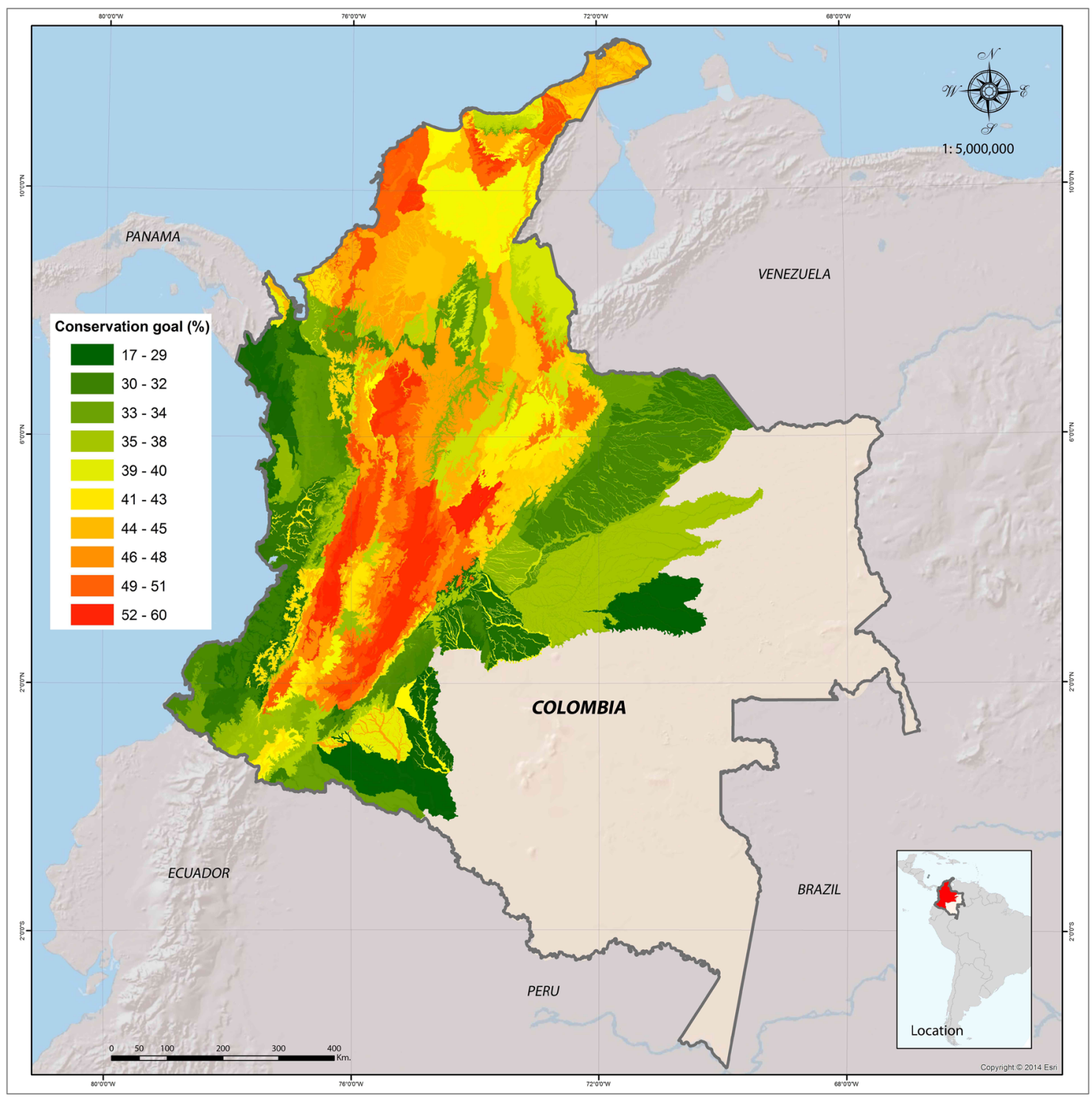

Figure 5. Map of conservation goals for the study area. 


\subsection{Prioritization of Key Areas (Where to Conserve?)}

A series of areas, totalling approximately $703,726 \mathrm{Km}^{2}$ ( $60 \%$ of the emerged land), were prioritized at a 1:100,000 scale. Of that area, $52 \%\left(365,434 \mathrm{Km}^{2}\right)$ was identified primordial for conservation, $47 \%$ is considered complementary and 0.52 has been already urbanized (cities, ways and infrastructure).

The prioritized areas (Figure 6) are constituted by those best pixels that reached the identified conservation goals in each Unit of Analysis. The best pixels are considered those with the best composition in terms of legal coverage, strategic ecosystems, integrity, connectivity, ecosystem services, opportunities for conservation, and land cover (Table 1). The use of a decision tree as a tool for prioritization allowed us to have a clearer and well defined way to select priority areas of conservation and additionally it allowed the identification of conservation mechanisms based on stakeholders, their jurisdiction and competence.

\subsection{Management Strategies (How to Conserve?)}

Management strategies were given to the prioritized and complementary areas. The complementary areas attempt to give additional information on the territory to stakeholders and decision-makers. Contrarily to other

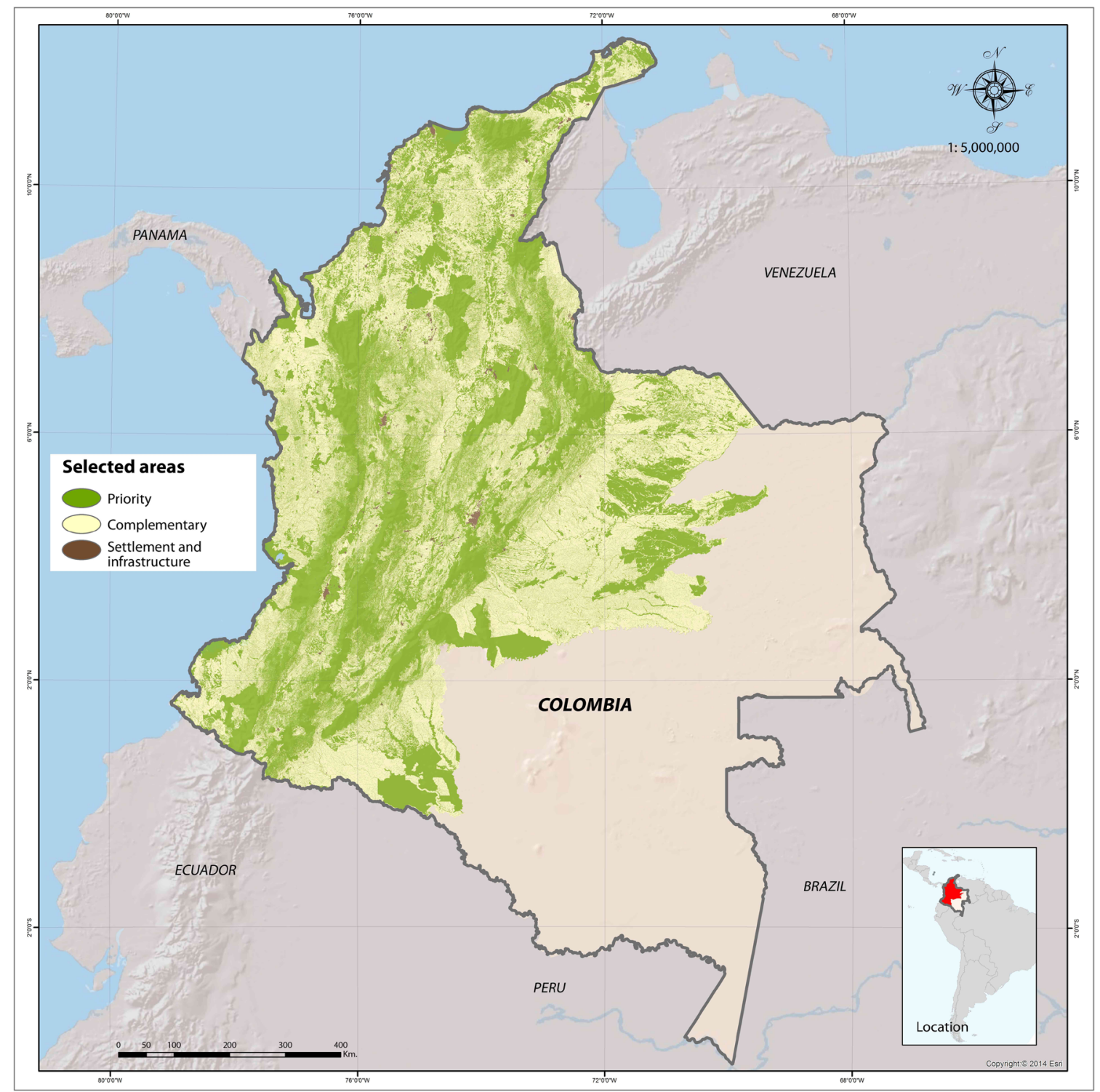

Figure 6. Priority and complementary areas for biodiversity conservation in $60 \%$ of the emerged territory of Colombia. 
prioritization portfolios, these areas are not presented as zeros on a map but as areas key for integral management and territorial planning strategies.

Management strategies aim to give an integral approach on how to manage the territory seeing it all as a whole (Table 5, Figure 7). The characterization of each pixel $(30 \mathrm{~m} \times 30 \mathrm{~m})$ by 29 different variables allowed the visualization and classification of the territory according to different perspectives, views and questions.

The results also show that the study area still encompasses interesting levels of naturalness covering approximate $338,752 \mathrm{Km}^{2}$ of the territory mentioned ( $\left.48 \%\right)$, with semi natural areas comprising $\sim 25 \%$ and transformed containing $\sim 26 \%$.

Of the totality of the territory assessed, $18 \%$ is already protected under two main strategies: Protected Areas (National or Regional and other within the Unique Register of Protected Areas) and Forest Reserves (Law $2^{\text {nd }}$ 1959). These areas have already been prioritized and are protected by law. However, their current and future conservation depends on the management given to these areas by the responsible authorities. Another $10 \%$ of the prioritized areas correspond to natural areas with important levels of integrity and connectivity, as well as natural areas within strategic ecosystems. These areas are proposed to be declared under any legal category of protection, either a protected area or another complementary conservation strategy, otherwise its naturalness can be lost along with its biodiversity, ecological processes and associated ecosystem services.

As the CBD states [51], complementary to the preservation strategy, restoration schemes are vital to mitigate and hopefully overcome the cumulative negative effects that have been deteriorating the country's ecosystems and peoples' wellbeing [68]. The results show that $78782.3 \mathrm{Km}^{2}(11.2 \%$ of the total of the study area), are suitable for any restoration strategy (restoration, rehabilitation and/or recuperation).

The proximity between the restoration and preservation sites presented in Figure 7 must be used to generate integrated initiatives to achieve complementarity and connectivity among areas. It should also be used to validate the methodology used for the identification of priority areas and the assignation of conservation strategies to aid territorial planning schemes.

In a developing country like Colombia, where its economy is based on the extraction of natural resources, it is key to understand the composition of the territory, its biodiversity, ecological processes and the ecosystem services provided. Natural, semi-natural and transformed areas cannot be managed and used in the same way. The complementarity of the strategies is relevant if a proper management of the territory, aiming at the conservation of its biodiversity but as well as the enhancement of the country's wellbeing, is pursued.

The territory, under the sustainable use strategy, corresponds to $77,242 \mathrm{Km}^{2}$ (10.9\%) of the research area. This strategy is divided in two, sustainable use of terrestrial resources and sustainable use for hydro-biological resources. The two ecosystems and its interphase have different needs and therefore different management options.

Table 5. Management strategies for $60 \%$ of the emerged territory of Colombia.

\begin{tabular}{|c|c|c|c|c|}
\hline & Main strategy & Strategies & $\mathrm{Km}^{2}$ & $\%$ \\
\hline \multirow{5}{*}{ Priority areas } & \multirow[b]{2}{*}{ Preservation } & Management of protected areas for the preservation of its biodiversity & 131709.2 & 18.7 \\
\hline & & $\begin{array}{l}\text { Implementation of complementary conservation strategies for the } \\
\text { preservation of the biodiversity. }\end{array}$ & 73893.0 & 10.5 \\
\hline & Restoration & Restoration & 78782.3 & 11.2 \\
\hline & \multirow{7}{*}{ Sustainable use } & Sustainable use of terrestrial resources & 61851.7 & 8.8 \\
\hline & & Sustainable use of hydro-biological resources & 15391.3 & 2.1 \\
\hline \multirow{5}{*}{$\begin{array}{l}\text { Complementary } \\
\text { areas }\end{array}$} & & Natural and semi-natural areas with high integrity or connectivity & 113363.6 & 16.1 \\
\hline & & $\begin{array}{l}\text { Natural and semi-natural areas with medium, low or } \\
\text { without integrity or connectivity }\end{array}$ & 115270.1 & 16.4 \\
\hline & & Transformed areas & 109404.2 & 15.5 \\
\hline & & Infrastructure & 3664.0 & 0.52 \\
\hline & & Total general & 703329.8 & 100 \\
\hline
\end{tabular}




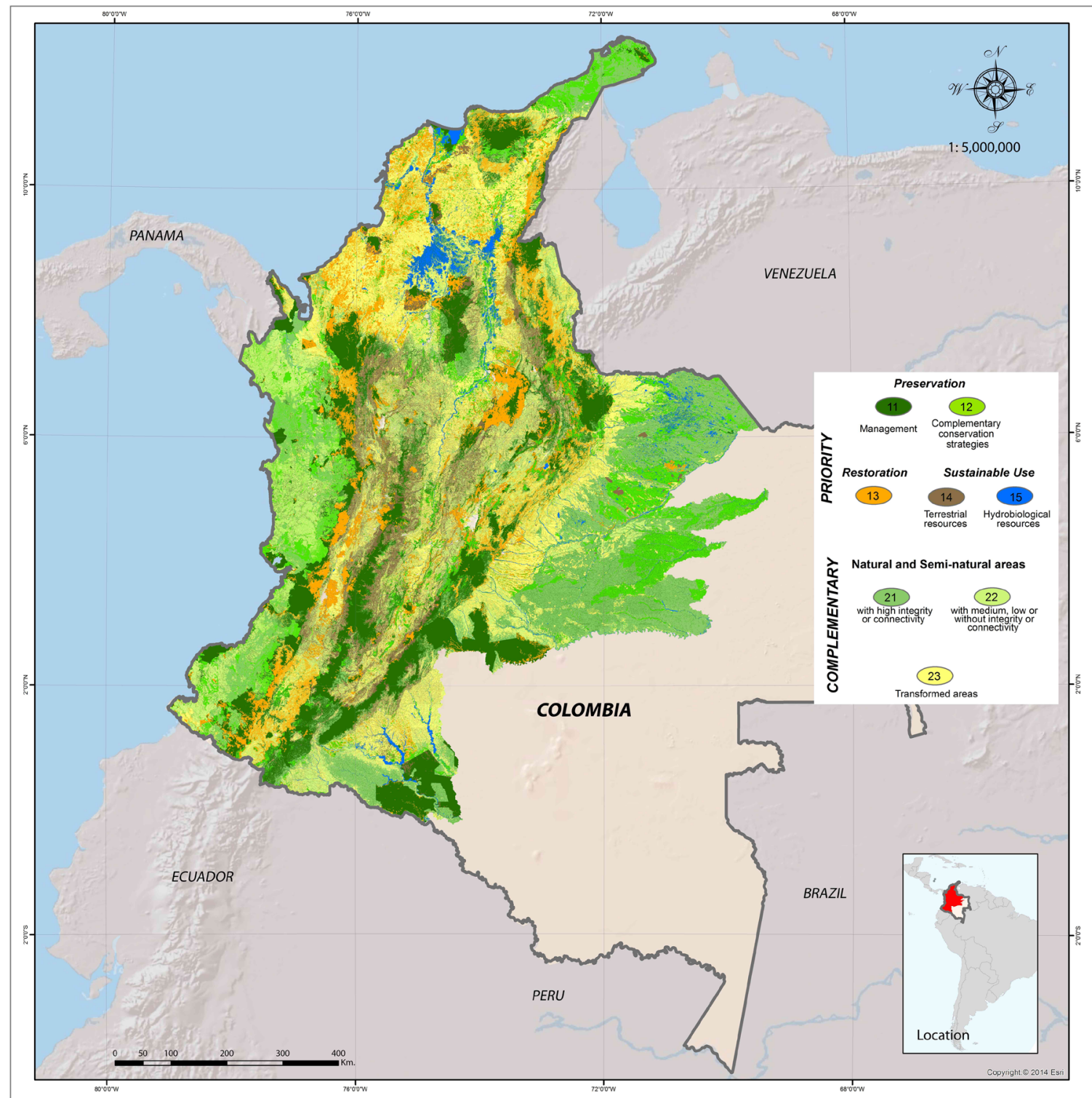

Figure 7. Conservation strategies for prioritized and complementary areas for $60 \%$ of the emerged territory of Colombia.

Due to the lack of information regarding freshwater ecosystems at a national scale and for management purposes, the only wetlands reserved for preservation purposes where those located within National and Regional Natural Parks, and Páramos (where they are legally protected), the rest are considered of common use therefore these were put under this strategy of conservation. More information regarded their conservation status is needed to classify them under the restoration strategy.

For complementary areas, the identification of strategies was done according to the naturalness and legal protection of the area. For the case of these areas, there were not found protected areas under the National System of Protected Areas, but areas under the jurisdiction of Indigenous, Afro-Colombian and rural communities were found. The combination of naturalness and legal protection resulted in three main categories: Natural and seminatural areas with high integrity or connectivity (within and outside Collective Territories) (16.1\%), Natural and semi-natural areas with medium, low or without integrity or connectivity (within and outside Collective Territories) (16.4\%) and transformed areas (15.5\%).

Having divided the territory into multiple strategies, it is intended to make the role of all stakeholders easier. For decision-makers either in the development sectors (oil, mining, agriculture, ranching, and infrastructure) and 
the national and regional environmental authorities, the information presented here constitutes a guideline for operation, planning and conservation schemes. If both sides use the information together, the results of their interventions on the territory should be less harmful to the national biodiversity and thus more intelligent and successful for the developing sectors.

\section{Discussion}

The most irreversible of human impacts on ecosystems is the loss of native biodiversity. According to the National Research Council of the United States [56] "the maintenance of biodiversity is one of the less intuitive ecosystem services that have been recognized”. Biodiversity is also about eating, staying healthy and finding shelter for plants, animals or humans. As Kaimowitz and Sheil [57] stated "it is not a question of 'either/or', but rather of finding a better balance", for this reason its protection and management have to be seen from an integral point of view including not only all the stakeholders ranging from users to both the conservation and environmental institutions and the development sectors [1] [58]-[60], but different approaches, strategies, actions that combined together are able to give solution to complex and multi-criteria scenarios.

Systematic territorial planning has traditionally been viewed as an important way to protect biological, environmental and social assets in terrestrial ecosystems [1] [17] [36] [61]-[65], and it is still in its infancy for freshwater ecosystem conservation. However, it represents one of the best strategies to meet the objectives of development and conservation, making it possible to have in the same territory the development, the protection and the sustainable use of the biodiversity [66].

Worldwide conservation initiatives, including the identification of key biodiversity areas, have started to be developed based on the valuation of ecological characteristics [64] [67] and allowing for development, wellbeing and prosperity programs. The alliance between Ecopetrol and the Humboldt Institute is one of the first in the country where a big part of the territory is considered and assessed systematically as a conservation and development strategy.

Trying to link a common point between conservation and development can be tricky and disappointing, but necessary and more important than ever [68]. The integration of conservation and development, through the generation of knowledge, could represent the only way that the effects of economic development and biodiversity loss can be minimized, mitigated or at least compensated, avoiding the net loss of biodiversity. As long as Colombia will continue to base its development and prosperity policies on the extraction of its natural resources, strategic ecosystems such as wetlands, Páramos, dry tropical forests and mangroves will probably suffer the most. For this reason it is urgent to formulate integrated conservation and development policies, initiatives and projects in high biodiversity areas to slowdown deterioration, and land and water conversion practices.

Ecopetrol participates in most of the steps of the chain of the oil sector, from the exploration and production to the transportation of oil and gas, to the manufacture of its products and their commercialization [69]. Each step implies risks and opportunities, either for the company, the regions where the activity is developed, or for the country. Minimizing those risks, by having better tools for territorial planning, will not only benefit the environment and their peoples, but also it will increase the company's profits and benefits.

The identification of areas suitable for preservation, restoration and sustainable use, provide the country with the proper tools to intervene and manage the landscape in a suitable way [51] [70]. These conservation strategies aim to protect the biodiversity and the provision of environmental services that support and contribute to the human wellbeing and in turn to the development and economic expansion processes of the country. Complementary areas are expected to serve as buffers to those priority areas, as well as to serve as a land bank where conservation strategies can be implemented and sustain and support those actions implemented in priority areas.

The information compiled here is enormous and its effectiveness will depend on the stakeholder and how it is used. Both Ecopetrol (and other enterprises of the sector) and the Regional Environmental Authorities (and other environmental actors) will be able to conduct their actions regarding biodiversity conservation and territorial planning, and compensations' obligations, within a clearer and more accurate panorama.

The decision tree used here included variables related to ecosystem services, strategic ecosystems, land use, patches integrity, legality of the land, and many others, constituting a new and efficient approach in its ability to identify areas that include a continuum of management options. According to De Ville [71], decision trees turn raw data into increased knowledge and awareness of scientific issues, and they enable you to deploy that knowledge in a simple but powerful set of understandable ideas. The methodology also allows the managers of 
the information to use it in real-time negotiations. Shape files for the decision tree can be renewed regularly having updated results. The transparency given by this tool allowed the characterization of pixels of $30 \mathrm{~m} \times 30$ $\mathrm{m}$ in 703,726 $\mathrm{Km}^{2}$, and in turn more accurate results [72]. Understanding the information contained in the territory in terms of geomorphology, biodiversity, ecosystem services, legal ownership, land use and so on, is necessary for any prioritization, landscape design or territorial planning scheme.

For this reason, it is expected that this information can contribute to the implementation of a National Decision-making Support System as another tool that could facilitate the collection, organization and analysis of environmental, social, economic and even policy data. This will make any decision-making process easier regarding biodiversity and territorial management, sectors' operations and planning [73] [74]. Complex solutions are needed to face complexity. Simpler solutions need to be left to countries and cases where the number of variables and their level of interaction are minor and controllable. Sometimes, simplicity rest importance to the important as well as to the complexity of the brain and its ability to create, transform and improve, things that can have an impact on the formulation and implementation of actions and strategies for biodiversity conservation and the management of the territory [75].

It is expected that many, including Ecopetrol, will benefit from these results and will conduct their operational and managerial activities, as well as direct their compensation schemes to fulfil the aims of each conservation strategy. In addition to having a better approach to the territory and to eventually reach a dynamic balance between the conservation and the correct use of the country's biodiversity. Other complementary conservation tools such as the analysis of probability of collapse of biodiversity [50] [76]-[80], the identification of conservation goals and surrogates (species), are not only useful but also necessary to contribute to a more robust and trustworthy systematic conservation-planning scheme.

\section{Conclusions}

Of the approximate 70 million of hectares of the study area, $52 \%$ of the assessed territory constitutes the area with the best environmental conditions positioning it as priority for the implementation of conservation strategies focused on preservation, restoration, and sustainable use. Complementary areas (the remaining $47 \%$ of the study area) have to be managed responsibly aiming at finding a balance between the remnant natural and seminatural ecosystems and the variety of human activities taking place on that territory.

The delimitation of the study area into conservation strategies constitutes a fundamental tool for the responsible management of the territory by the proper stakeholders (environmental authorities, productive sectors, civil society). This is all the more significant in a very complex area that includes two coast, three mountain ranges, five main river basins, and a variety of biomes, eco-regions and ecosystems, fundamental for the country in terms of biodiversity, and social and economic development.

The methodology used for the prioritization of key areas allows the discrimination among a universe of possibilities, giving concrete conservation objectives through solid criteria, making easier and more efficient the implementation of conservation measures.

It is important to break the paradigm of conservation vs. development, and to start working together to reach mutual points that will try to highlight the importance of understanding the way natural resources and their processes act upon our daily activities and the economies of cities, countries and regions. Breaking this paradigm will allow the institutions in charge of studying and protecting the biodiversity to work hand to hand with the companies exploiting the natural resources, in this way it will be possible to generate the adequate synergies that integrate biodiversity conservation and economic development.

The determination of the complexity of the reality of a situation allows the implementation of interdisciplinary tools to interpret it in the most adequate and efficient way. In a complex country with complex biodiversity, people, stakeholders and sometimes policies, complex tools, strategies and answers are need.

The more detailed the conservation methodologies are, the more detailed and accurate the conservation strategies are implemented. However, uncertainty is a key variable within many of the strategies in tropical countries and for this reason it is important to consider the flexibility of socio-ecological systems regarding uncertainty to decrease any possible error during the formulation and/or implementation of these strategies. Different geographic scales, external investment and new methodologies, infrastructure and markets framed in the reality of economic development and natural resources overexploitation, are needed.

Colombia provides an excellent prospect to develop and perfect a Decision-making Support System. The use 
of transparent methods of prioritization allows the effective replication of the proceedings and their adaptation to particularities. It also can be a starting point to develop landscape design exercises considering an integral management of the country's biodiversity and its associated ecosystem services. However it is necessary to gather more detailed information on land ownership and ecosystem conservation status.

According to the assessments, Colombia has already reached its commitments regarding Protected Areas coverage. However many obstacles need to be overcome to have a fully and successful management of these Areas. The proper implementation of the law would allow the Protected Areas System to reach conservation goals and objectives in addition to finding the balance between the conservation of the local biodiversity and the prosperity and wellbeing of the local communities associated to these areas that in some cases are part of the threats that impact the PAs, however most of the time local communities are opportunities of conservation. It is important to analyse the role of private property within conservation strategies and its effects providing effective governance for common pool resources.

The long list of conservation surrogates is just an example of the extreme richness of Colombia. A better understanding of these species is needed, however in the meantime their use as national, regional and local surrogates of conservation is fundamental to protect specific ecosystems and habitats, as well as ecological processes. The species selected will have a set of management and conservation strategies and guidelines that will be provided to the Regional Environmental Authorities as well as to Ecopetrol that will enforce their conservation through a series of scholarships that will be provided to students and researchers nationwide.

Finally, Colombia is going through a Peace Talk process, which hopefully will end up resulting in a winning solution to all Colombians. For this reason, a post-conflict scenario needs to be considered within conservation, development and management plans.

\section{Acknowledgements}

The authors of this paper want to thank Hernando García, Javier Barriga, Diego Cordoba, Catalina Sosa, Luz Marina Silva, and Federico Pardo from the Humboldt Institute and researchers of this project, also thanks to the Colombian Oil Company Ecopetrol, especially to Jorge Alberto Rodriguez Roa, Andrés Pavia Pedraza, and Ana Maria Moncaleano from the HSE direction. Also thanks to Dr. Brigitte Baptiste General Director of the Humboldt Institute, Germán Andrade Sub-Director of the Humboldt Institute, Jerónimo Rodríguez Sub-Director of special projects of the Humboldt Institute, Carlos Lasso, Carlos Tapia, Juan Carlos Bello, Program Coordinators within the Humboldt Institute for their invaluable inputs to this project. To Ana María Hernández from International Cooperation of the Humboldt Institute, finally to the Information on Biodiversity System [Sistema de Información sobre Biodiversidad-SIB Colombia] for integrating systematic results on species' databases. Special thanks to David Kieckbusch for revising the manuscript and to Patricia Murcia for translating maps and tables. Finally, thanks to Erika Peñuela and Jenny Sanchez, for their constant collaboration throughout the project.

\section{References}

[1] Portocarrero-Aya, M. (2012) Conservation of the Freshwater Biodiversity in Key Areas of the Colombian Amazon. Ph.D. Thesis, University of Hull, Hull.

[2] Brechin, S.R., Wilshusen, P.R., Fortwangler, C.L. and West, P.C. (2002) Beyond the Square Wheel: Toward a More Comprehensive Understanding of Biodiversity Conservation as Social and Political Process. Society and Natural Resources, 15, 41-64.

[3] National Development Plan (2011) National Development Plan 2010-2014. Prosperity to All. Republic of Colombia.

[4] National Development Plan (2003) National Development Plan 2002-2006. To a Community State. Republic of Colombia.

[5] MADS (Ministry of Environment and Sustainable Development) (2013) National Policy for the Integral Management of Biodiversity and Its Ecosystemic Services (PNGIBSE). Republic of Colombia.

[6] Armenteras, D., Rodríguez, N., Retana, J. and Morales, M. (2010) Understanding Deforestation in Montane and Lowland Forests of the Colombian Andes. Regional Environmental Change, 11, 693-705. http://dx.doi.org/10.1007/s10113-010-0200-y

[7] Asher, K. and Ojeda, D. (2009) Producing Nature and Making the State: Ordenamiento Territorial in the Pacific Lowlands of Colombia. Geoforum, 40, 292-302. http://dx.doi.org/10.1016/j.geoforum.2008.09.014

[8] Read, D. (2002) Biodiversity Conservation in the Wider Caribbean Region. Review of European Community and In- 
ternational Environmental Law, 11, 74-8. http://dx.doi.org/10.1111/1467-9388.00304

[9] Rodríguez Eraso, N., Armenteras-Pascual, D. and Retana Alumbreros, J. (2012) Land Use and Land Cover Change in the Colombian Andes: Dynamics and Future Scenarios. Journal of Land Use Science.

[10] TEEB (2010) The Economics of Ecosystems and Biodiversity for Local and Regional Policy Makers.

[11] Sayer, J. (2009) Can Conservation and Development Really Be Integrated? Madagascar Conservation and Development 4.

[12] Abell, R., Allan, J.D. and Lenher, B. (2007) Unlocking the Potential for Protected Areas in Conserving Freshwaters. Biological Conservation, 134, 48-63.http://dx.doi.org/10.1016/j.biocon.2006.08.017

[13] Corzo, G., Londoño-Murcia, M.C., Ramírez, W., García, H., Lasso, C.A. and Salamanca, B., Eds. (2011) Environmental Planning for Biodiversity Conservation within the Operational Areas of Ecopetrol: Magdalena Medio and Llanos Orientales of Colombia. Instituto Alexander von Humboldt y Ecopetrol S.A., Bogotá D.C., Colombia.

[14] Gaston, K.J., Pressey, R.L. and Margules, C.R. (2002) Persistence and Vulnerability: Retaining Biodiversity in the Landscape and in Protected Areas. Journal of Biosciences, 27, 361-384.http://dx.doi.org/10.1007/BF02704966

[15] Hoyt, E. (2011) Marine Protected Areas for Whales, Dolphins and Porpoises: A World Handbook for Cetacean Habitat Conservation and Planning. 2nd Edition, Earthscan, London.

[16] Koehn, J. (2003) Riverine Aquatic Protected Areas: Protecting Species, Communities or Ecosystem Processes? In: Beumer, J.P., Grant, A. and Smith, D.C., Eds., Aquatic Protected Areas-What Works Best and How Do We Know? Proceedings of the World Congress on Aquatic Protected Areas, University of Queensland, Cairns.

[17] Margules, C.R. and Pressey, R.L. (2000) Systematic Conservation Planning. Nature, 405, 243-253. http://dx.doi.org/10.1038/35012251

[18] MADS (Ministry of Environment and Sustainable Development), UNDP (United Nations Development Programme) (2014) Fifth National Report on Colombian Biodiversity-Convention on Biological Diversity. Bogotá, D.C., Colombia.

[19] Pittock, J., Hansen, L.J. and Abell, R. (2008) Running Dry: Freshwater Biodiversity, Protected Areas and Climate Change. Biodiversity, 9, 30-38. http://dx.doi.org/10.1080/14888386.2008.9712905

[20] Suski, C.D. and Cooke, S.J. (2007) Conservation of Aquatic Resources through the Use of Freshwater Protected Areas: Opportunities and Challenges. Biodiversity and Conservation, 16, 2015-2029. http://dx.doi.org/10.1007/s10531-006-9060-7

[21] Cowling, R., Pressey, R., Sims-Castley, R., Le Roux, A., Baard, E., Burgers, C. and Palmer, G. (2003) The Expert or the Algorithm?-Comparison of Priority Conservation Areas in the Cape Floristic Region Identified by Park Managers and Reserve Selection Software. Biological Conservation, 112, 147-167. http://dx.doi.org/10.1016/S0006-3207(02)00397-X

[22] Grantham, H.S., Pressey, R.L., Wells, J.A. and Beattie, A.J. (2010) Effectiveness of Biodiversity Surrogates for Conservation Planning: Different Measures of Effectiveness Generate a Kaleidoscope of Variation. PLoS ONE, 5, e11430. http://dx.doi.org/10.1371/journal.pone.0011430

[23] Groves, C.R. (2003) Drafting a Conservation Blueprint: A Practitioner's Guide to Planning Biodiversity. The Nature Conservancy, Washington DC, Arlington, Virginia.

[24] Pressey, R.L., Possingham, H.P. and Margules, C.R. (1996) Optimality in Reserve Selection Algorithms: When Does It Matter and How Much? Biological Conservation, 76, 259-267. http://dx.doi.org/10.1016/0006-3207(95)00120-4

[25] Pressey, R.L., Possingham, H.P. and Day, J.R. (1997) Effectiveness of Alternative Heuristic Algorithms for Approximating Minimum Requirements for Conservation Reserves. Biological Conservation, 80, 207-219. http://dx.doi.org/10.1016/S0006-3207(96)00045-6

[26] Pressey, R.L., Possingham, H.P., Logan, V.S., Day, J.R. and Williams, P.H. (1999) Effects of Data Characteristics on the Results of Reserve Selection Algorithms. Journal of Biogeography, 26, 179-191. http://dx.doi.org/10.1046/j.1365-2699.1999.00258.x

[27] Sarkar, S., Pressey, R.L., Faith, D.P., Margules, C.R., Fuller, T., Stoms, D.M., Moffett, A., Wilson, K.A., Williams, K.J., Williams, P.H. and Andelman, S. (2006) Biodiversity Conservation Planning Tools: Present Status and Challenges for the Future. Annual Review of Environment and Resources, 31, 123-159. http://dx.doi.org/10.1146/annurev.energy.31.042606.085844

[28] Filipe, A.F., Marques, T.A., Seabra, S., Tiago, P., Ribeiro, F., Costa, L.M.D.A. and Cowx, I.G. (2004) Selection of Priority Areas for Fish Conservation in Guadiana River Basin, Iberian Peninsula. Conservation Biology, 18, $189-200$. http://dx.doi.org/10.1111/j.1523-1739.2004.00620.x

[29] Csuti, B., Polasky, S., Williams, P.H., Pressey, R.L., Camm, J.D., Kershaw, M., Kiester, A.R., Downs, B., Hamilton, R., Huso, M. and Sahr, K. (1997) A Comparison of Reserve Selection Algorithms Using Data on Terrestrial Verte- 
brates in Oregon. Biological Conservation, 80, 83-97. http://dx.doi.org/10.1016/S0006-3207(96)00068-7

[30] Koleff, P. and Urquiza-Haas, T. (2011) Planning for the Conservation of the Terrestrial Biodiversity in Mexico : Challenges in a Mega-Diverse Country. National Commission for the Knowledge and Use of Biodiversity, National Commission on National Protected Areas, México.

[31] The World Bank (2014) World Development Indicators. The GINI Index. http://data.worldbank.org/indicator/SI.POV.GINI/countries/NO?page=1\&display=map

[32] Moilanen, A., Arponen, A., Stoklans, J.N. and Cabeza, M. (2005) Assessing Replacement Cost of Conservation Areas: How Does Habitat Loss Influence Priorities? Biological Conservation, 142, 575-585. http://dx.doi.org/10.1016/j.biocon.2008.11.011

[33] Sarkar, S. and Margules, C. (2002) Operationalizing Biodiversity for Conservation Planning. Journal of Biosciences, 27, 299-308. http://dx.doi.org/10.1007/BF02704961

[34] Kelley, C., Garson, J., Aggarwal, A. and Sarkar, S. (2002) Place Prioritization for Biodiversity Reserve Network Design: A Comparison of the SITES and ResNet Software Packages for Coverage and Efficiency. Diversity and Distributions, 8, 297-306. http://dx.doi.org/10.1046/j.1472-4642.2002.00155.x

[35] Strecker, A. and Olden, J. (2011) Defining Conservation Priorities for Freshwater Fishes According to Taxonomic, Functional, and Phylogenetic Diversity. Ecological Applications, 21, 3002-3013. http://dx.doi.org/10.1890/11-0599.1

[36] Warman, L. and Sinclair, A. (2000) A Systematic Method for Identifying Priority Conservation Areas Using Wildlife Habitat Relationships and Observed Locations of Rare Species. In: Hollstedt, C., Sutherland, K. and Innes, T., Eds., From Science to Management and Back: A Science Forum for Southern Interior Ecosystems of British Columbia, Southern Interior Forest Extension and Research Partnership, Kamloops, B.C., 141-144.

[37] Andrade, G.I. and Corzo, G. (2011) What and Where to Conserve? National Natural Parks of Colombia, Bogotá.

[38] Fandiño-Lozano, M. and Van Wyngaarden, W. (2005) Biological Conservation Priorities for Colombia. ARCO Group, Bogotá.

[39] Lasso, C.A., Rial, A., Matallana, C., Ramirez, W. Señaris, J., Diaz-Pulido, A., Corzo, G. and Machado-Allizon, A., Eds. (2011) Biodiversity of the Orinoco River Basin. II Priority Areas for Conservation and Sustainable Use. Alexandervon Humboldt Institute for Research on Biological Resources, Ministry of Environment, Housing and Territorial Development, WWF Colombia, Omacha Foundation, Foundation La Salle of Natural Sciences and Orinoquia Studies Institute (National University of Colombia), Bogotá, Colombia.

[40] Fisher, B. and Christopher, T. (2007) Poverty and Biodiversity: Measuring the Overlap of Human Poverty and the Biodiversity Hotspots. Ecological Economics, 62, 93-101. http://dx.doi.org/10.1016/j.ecolecon.2006.05.020

[41] Harris, N.L., Petrova, S., Stolle, F. and Brown, S. (2008) Identifying Optimal Areas for REDD Intervention: East Kalimantan, Indinesia as a Case Study. Environmental Research Letters, 3, Article ID: 035006. http://dx.doi.org/10.1088/1748-9326/3/3/035006

[42] Morales, M., Otero, J., Van der Hammen, T., Torres, A., Cadena, C., Pedraza, C., Rodríguez, N., Franco, C., Betancourth, J.C., Olaya, E., Posada, E. and Cárdenas, L. (2007) Atlas of Paramos of Colombia. Alexandervon Humboldt Institute for Research on Biological Resources, Bogotá.

[43] Caro, M.T. and O’Doherty, G. (1999) On the Use of Surrogate Species in Conservation Biology. Conservation Biology, 13, 805-814. http://dx.doi.org/10.1046/j.1523-1739.1999.98338.x

[44] Abell, R., Thieme, M., Dinerstein, E. and Olson, D. (2002) A Sourcebook for Conducting Biological Assessments and Developing Biodiversity Visions for Ecoregion Conservation. Volume II: Freshwater Ecoregions. World Wildlife Fund, Washington DC.

[45] CI (Conservation International) (2008) Delimitation of Key Conservation Areas (KBA) in the Colombian Portion of the Northern-Andean Corridor. Biocolombia, Conservation International, Bogota, Colombia.

[46] TNC (The Nature Conservancy) (2000) Eco-Regional Aquatic Planning. Freshwater Initiative, The Nature Conservancy.

[47] Loyola, R.D., De Oliveira, G., Diniz-Filho, J.A.F. and Lewinsohn, T.M. (2008) Conservation of Neotropical Carnivores under Different Prioritization Scenarios: Mapping Species Traits to Minimize Conservation Conflicts. Diversity and Distributions, 14, 949-960. http://dx.doi.org/10.1111/j.1472-4642.2008.00508.x

[48] Coppolillo, P., Gomez, H., Maisels, F. and Wallace, R. (2003) Selection Criteria for Suites of Landscape Species as a Basis for Site-Based Conservation. Biological Conservation, 115, 419-430. http://dx.doi.org/10.1016/S0006-3207(03)00159-9

[49] Myers, N., Mittermeier, R.A., Mittermeier, C.G., da Fonseca, G.A.B. and Ken, J. (2000) Biodiversity Hotspots for Conservation Priorities. Nature, 403, 853-858. http://dx.doi.org/10.1038/35002501

[50] Portocarrero-Aya, M., Hernández-Manrique, O.L. and Corzo, G. (in press) Probability of Biodiversity Collapse in 
Some Colombian Socio-Ecosystems. In: von Humboldt, A., Biodiversity 2014 (in press), Institute for Research on Biological Resources, Bogotá, Colombia.

[51] CBD (Convention on Biological Diversity) (2011) Strategic Plan for Biodiversity 2011-2020, Including Aichi Biodiversity Targets. https://www.cbd.int/sp/

[52] Pressey, R.L., Cabeza, M., Watts, M.E., Cowling, R.M. and Wilson, K.A. (2007) Conservation Planning in a Changing World. Trends in Ecology Evolution, 22, 583-592. http://dx.doi.org/10.1016/j.tree.2007.10.001

[53] Tear, T.H., Karieva, P., Angermeier, P.L., Comer, P., Czech, B., Kautz, R., Landon, L., Mehlman, D., Murphy, K., Ruckelshaus, M., Scott, J.M. and Wilhere, G. (2005) How Much Is Enough? The Recurrent Problem of Setting Measurable Objectives in Conservation. Bioscience, 55, 835-849. http://dx.doi.org/10.1641/0006-3568(2005)055[0835:HMIETR]2.0.CO;2

[54] Etter, A. (1991) Introduction to Landscape Ecology: An Integrative Framework for Rural Sampling. Geographic Institute Agustín Codazzi, IGAC, Bogotá, Colombia.

[55] MAVDT (Ministry of Environment and Sustainable Development) (2010) National Plan of Restoration. Ecological Restoration, Rehabilitation and Recovery of Disturbed Areas. Ministry of Environment and Sustainable Development, Bogotá, Colombia.

[56] National Research Council (2004) Valuing Ecosystem Services: Toward Better Environmental Decision-Making. Committee on Assessing and Valuing the Services of Aquatic and Related Terrestrial Ecosystems. The National Academies Press, Washington DC.

[57] Kaimowitz, D. and Sheil, D. (2007) Conserving What and for Whom? Why Conservation Should Help Meet Basic Human Needs in the Tropics. Biotropica, 39, 567-574. http://dx.doi.org/10.1111/j.1744-7429.2007.00332.x

[58] Silva, M. (2005) The Brazilian Protected Areas Program. Conservation Biology, 19, 608-611. http://dx.doi.org/10.1111/j.1523-1739.2005.00707.x

[59] Rodrigues, A.S., Cerdeira, J.O. and Gaston, K.J. (2000) Flexibility, Efficiency, and Accountability: Adapting Reserve Selection Algorithms to More Complex Conservation Problems. Ecography, 23, 565-574. http://dx.doi.org/10.1034/j.1600-0587.2000.230507.x

[60] Davis, F.W., Stoms, D.M., Costello, C.J. and Machado, E.A. (2003) A Framework for Setting Land Conservation Priorities Using Multi-Criteria Scoring and an Optimal Fund Allocation Strategy. University of California, Santa Barbara, National Center for Ecological Analysis and Synthesis, Report to The Resources Agency of California.

[61] Almeida, P., Cortés, K., Menéndez, P., Bauz, E., Rodríguez, M., Toaza, G., Álvarez, U., Pinos, G., Yumiseva, L.S.C. and Lara, M. (2003) Identification of Priority Areas for Conservation in Five Eco-Regions of Latin America, GEF/ 1010-00-14.

[62] Phillips, S.J. and Dudík, M. (2008) Modelling of Species Distributions with Maxent: New Extensions and a Comprehensive Evaluation. Ecography, 31, 161-175. http://dx.doi.org/10.1111/j.0906-7590.2008.5203.x

[63] Hoffmann, M., Brooks, T.M., da Fonseca, G.A.B., Gascon, C., Hawkins, A.F.A., James, R.E., Langhammer, P., Mittermeier, R.A., Pilgrim, J.D., Rodrigues, A.S.L. and Silva, J.M.C.S. (2008) Conservation Planning and the IUCN Red List. Endangered Species Research, 6, 113-125.

[64] Leathwick, J.R., Moilanen, A., Ferrier, S. and Julian, K. (2010) Complementarity-Based Conservation Prioritization Using a Community Classification, and Its Application to Riverine Ecosystems. Biological Conservation, 143, 984-991. http://dx.doi.org/10.1016/j.biocon.2010.01.012

[65] Warman, L.D., Sinclair, A.R.E., Scudder, G.G.E., Klinkenberg, B. and Pressey, R.L. (2004) Sensitivity of Systematic Reserve Selection to Decisions about Scale, Biological Data, and Targets: Case Study from Southern British Columbia. Conservation Biology, 18, 655-666. http://dx.doi.org/10.1111/j.1523-1739.2004.00538.x

[66] MDG (Millennium Development Goals) (2005) A Practical Plan to Achieve the Millennium Development Goals. United Nation Development Program. http://www.unmillenniumproject.org/reports/fullreport.htm

[67] Nori, J., Lescano, J.N., Illoldi-Rangel, P., Frutos, N., Cabrera, M.R. and Leynaud, G.C. (2013) The Conflict between Agricultural Expansion and Priority Conservation Areas: Making the Right Decisions before It Is Too Late. Biological Conservation, 159, 507-513.

[68] Butchart, S., Walpole, M. and Collen, B. (2010) Global Biodiversity: Indicators of Recent Declines. Science, 328, 1164-1168. http://dx.doi.org/10.1126/science.1187512

[69] Ecopetrol (2012) Reporte Integrado de Gestión Sostenible 2011. http://www.ecopetrol.com.co/especiales/ReporteGestion2012/pdf/ri2011.pdf

[70] SER (Society for Ecological Restoration International Science \& Policy Writing Group) (2006) The SER International Primer on Ecological Restoration. Society for Ecological Restoration International, Tucson. http://www.ser.org 
[71] De Ville, B. (2007) Decision Trees for Business Intelligence and Data Mining: Using SAS Enterprise Miner. SASPUB. USA.

[72] Murthy, S. and Salzberg, S. (1995) Decision Tree Induction: How Effective Is the Greedy Heuristic? KDD-95 Proceedings, 222-227.

[73] Pressey, R.L. and Cowling, R.M. (2001) Reserve Selection Algorithms and the Real World. Conservation Biology, 15, 275-277.http://dx.doi.org/10.1046/j.1523-1739.2001.99541.x

[74] Druzdzel, M.J. and Flynn, R.R. (2002) Decision Support Systems. In: Kent, A., Ed., Encyclopedia of Library and Information Science, 2nd Edition, Marcel Dekker, Inc., New York.

[75] Carrizosa-Umaña, J. (2014) Complex Colombia. Boptanical Garden of Bogotá José CelestinoMutis. Alexander von Humboldt Institute for Research on Biological Resources, Bogotá, D.C., Colombia.

[76] Rodriguez, J.P., Rodriguez-Clark, K., Baillie, J.E.M., Ash, N., Benson, J., Boucher, T., Brown, C., Burgess, N.D., Collen, B., Jennings, M., Keith, D.A., Nicholson, E., Revenga, C., Reyers, B., Rouget, M., Smith, T., Spalding, M., Taber, A., Walpole, M., Zager, I. and Zamin, T. (2011) Definition of IUCN Categories for Threatened Ecosystems. Conservation Biology, 25, 21-29.

[77] EPA (Environmental Protection Agency) (1992) Framework for Ecological Risk Assessment. Risk Assessment Forum U.S. Environmental Protection Agency, Washington DC.

[78] Hernández-Manrique, O.L. and Hurtado, A. (2012) Ecology Functionality Analysis. In: Hurtado, A., Ed., Analysis of the Diversity, Distribution and State of Threat of Five Taxonomical Groups, Conservation Landscape Integrity and Functionality in Los Katíos, Final Reports, Ecotropico-WWF Colombia.

[79] IDEAM (Institute of Hydrology, Meteorology and Environmental Studies) (2010) Second Communication on Climate Change-United National Convention. Republic of Colombia.

[80] Wilson, K., Pressey, R.L., Newton, A., Burgman, M., Possinham, H. and Weston, C. (2005) Measuring and Incorporating Vulnerability into Conservation Planning. Environmental Management, 35, 527-543. http://dx.doi.org/10.1007/s00267-004-0095-9 


\section{Appendix}

Terrestrial Analysis Units for $60 \%$ of the Colombian territory.

\section{aribbean}

UA_1011, Dry Zonobiome of the Caribbean in lower Guajira - upper Cesar

UA 1019. Dry Zonobiome of the Caribbean of upper Guajira

UA_1041, Orobiome with sub-Andean azonal forest of Santa Marta

UA_1040, Orobiome with high Andean forest of Santa Marta in Chundua North

UA 1028, Orobiome with high Andean forest of Santa Marta in Chundua

UA 1042, Orobiome with sub-Andean forest of Santa Marta in the Aracataca North

UA_1038, Halobiome of the Caribbean in Guachaca

UA_1020, Halobiome of the Lower Magdalena

UA_1032, Orobiome with Andean forest of Santa Marta in Aracataca

UA_1025, Humid Zonobiome of the rivers valley of Sinú and San Jorge

UA_1043, Orobiome with sub-Andean forest of Santa Marta in the North of Marocaso

UA_1015, Dry Zonobiome of the Caribbean in Sinú - San Jorge

UA_1051, Dry Zonobiome of the Caribbean in the North of Marocaso

UA 1027, Dry Zonobiome of the Caribbean in the South of Cartagena

UA_1053, Paramo of Sierra Nevada of Santa Marta

UA_1030, Orobiome with sub-Andean forest of Santa Marta in Aracataca

UA_1017, Halobiome of the upper Guajira

UA 1035, Halobiome of the Caribbean in Guachaca

UA_1052, Dry Zonobiome of the Caribbean in Guachaca

UA_1037, Halobiome of the Caribbean to the North of the Sierra Nevada

UA_1002, Halobiome of the Caribbean in The Delta of Magdalena

UA_1049, Azonal dry Zonobiome of Santa Marta

UA_1047, Orobiome with Andean forest of Santa Marta in the North of Marocaso

UA_1048, Orobiome with Andean forest of Santa Marta in Guachaca

UA_1008, Halobiome of the Magdalena in the Monts of Maria and Piojo

UA_1044, Orobiome with sub-Andean forest of Santa Marta in Guachaca

UA_1039, Orobiome with high Andean forest of the Santa Marta in Aracataca

UA_1014, Dry Zonobiome of the Caribbean in Monts of Maria and Piojó

UA_1046, Orobiome with Andean forest of Santa Marta in the North of Aracataca

UA_1031, Orobiome with sub-Andean forest of Santa Marta in Marocaso

UA_3100, Orobiome with sub-Andean forest Macuira

UA_1003, Halobiome of the Lower Magdalena in Sinú - San Jorge

UA 1021, Halobiome of the Caribbean in Sinu - San Jorge

UA_1016, Halobiome of the Caribbean in the upper Guajira

UA_2039, Dry Zonobiome of the Caribbean in Turbo

UA_1050, Dry Zonobiome of the Caribbean in lower Guajira - upper Cesar North

UA_1009, Humid Zonobiome in Sinú - San Jorge

UA_1018, Xerophytic Zonobiome in the upper Guajira

UA_1022, Halobiome of the Caribbean in Turbo

UA_1001, Halobiome of the Caribbean in Cartagena

UA_1013, Dry Zonobiome of the Caribbean in Cartagena Delta

UA_1010, Dry Zonobiome of the Caribbean in Ariguani - Cesar

UA_1033, Orobiome with Andean forest of Santa Marta in Marocaso

UA_1023, Halobiome of the Magdalena in Sinu - San Jorge

UA_1007, Halobiome of the Magdalena in the Delta of Magdalena

UA_1029, Orobiome with sub-Andean forest of Santa Marta in the upper Cesar

UA_1004, Halobiome of the Caribbean of the Lower Guajira

UA_1026, Dry Zonobiome of the Caribbean of Uraba - Sinu

UA_1012, Dry Zonobiome of the Caribbean in Cartagena

UA_1024, Humid Zonobiome of the Caribbean in Sinú

UA_1006, Halobiome of the Magdalena in Cartagena

UA_1005, Halobiome of the Magdalena of Ariguani - Cesar 


\section{Pacific}

UA_2035, Halobiome of the Pacicic in Baudo

UA_2001, Halobiome of the Pacific in the Micay

UA_2028. Humid Zonobiome of the Pacific in Barbacoas

UA_2026, Halobiome of the Pacific in Tumaco

UA 2043. Halobiome of the Piedmont Utria

UA_3084, Orobiome of Darien in Aspavé - El Limón - San Pirr

UA_2024, Halobiome of the Pacific in Tumaco

UA 2030. Humid Zonobiome of the Pacific piedmont in the upper Patia

UA 3088, Orobiome of Darien in Tacarcuna- Acandí - San Blass

UA_2017. Humid Zonobiome of the Atrato in Murri

UA 2002. Halobiome of the Pacific in Micay

UA 2041. Orobiome of Baudo in Utria

UA_2023, Halobiome of the Pacific in Jurado

UA_3151, Orobiome of Baudo

UA_2010, Halobiome of the Atrato in Aspavé - El Limón - Pirr

UA_2020, Humid Zonobiome of the Caribbean in Turbo

UA 2038. Humid Zonobiome of the Pacific piedmont in the upper Atrato - San Juan

UA 3086, Orobiome of Baudo in the upper Atrato

UA_2007, Halobiome of the Atrato

UA_2037, Humid Zonobiome of the Pacific in the Baudo

UA_2004, Humid Zonobiome of the Pacific piedmont in the Canyon of Dagua

UA 2015, Halobiome of the Pacific in Murri

UA 2034, Halobiome of the Pacific in Atrato - San Juan

UA_2036, Humid Zonobiome of the Pacific in the upper Atrato - San Juan

UA_2029. Humid Zonobiome of the Pacific in Tumaco

UA_2003, Humid Zonobiome of the Pacific in Micay

UA_2005, Humid Zonobiome of the Pacific piedmont in Micay

UA_2008, Halobiome of the Atrato in Necocli

UA 2022. Humid Zonobiome of the Pacific piedmont in Murri

UA_3087, Orobiome of Baudo in the Lowes Atrato

UA_2025, Halobiome of the Pacicic in Barnacoas

UA 2006. Halobiome of the Gulf of Uraba

UA_2021, Humid Zonobiome of the Pacific in the Lowest Atrato

UA_2016, Humid Zonobiome of the Atrato in Aspavé - El Limón - Pirr

UA_2019. Humid Zonobiome of the Atrato in Tacarcuna - Acandi - San Blas

UA_2014. Halobiome of the Atrato in Turbo

UA 2042. Humid Zonobiome of the Pacific in Utria

UA 2018. Humid Zonobiome of the Atrato in Riosucio

UA 2032. Halobiome of the Pacific in the San Juan

UA 2031. Humid Zonobiome of the Pacific piedmont in Barbacoas

UA 3111. Orobiome of Baudo and Darien in Jurado

UA_3085, Orobiome of Baudo in the upper Atrato

UA_2012, Halobiome of the Atrato in Riosucio

UA_2040, Halobiome of the Pacific in Utria

\section{Andes}

UA_3065, Sub-xerophytic zonobiome in the Valle of the Magdalena River

UA 3101, Orobiome with sub-Andean forest eastern cordillera of the Catatumbo Montains

UA_3150, Orobiome with sub-Andean forest western slope Western cordillera

UA_3120, Humid orobiome with Western Andean forest of the Eastern cordillera

UA_3056, Orobiome with Andean and high Andean forest of Huila and Caqueta western slope of the Eastern Cordillera

UA 3152, Orobiome with Andean and high Andean forest western slope of the Eastern in Sogamoso

UA_3044, Orobiome with Andean and high Andean forest of Huila and Caqueta western slope of the Eastern Cordillera

UA 3070. Humid Zonobiome of the river valley in the western slope of the eastern cordillera 
les (cont.)

UA_3130, Humid Zonobiome of the river valley of Magdalena in San Lucas

UA_3128, Humid Zonobiome of the river valley of Magdalena in the Lebrija

UA_3030, Paramo of Sonsón

UA_3025, Paramo of Paramillo

UA_3022, Paramo of the Picachos

UA_3010, Paramo of Doña Juana - Chimayoy

UA_3115, Orobiome with sub-Andean forest of the Serrania San Lucas

UA_3131, Dry Zonobiome in the Gloria

UA_3068, Sub-xerophytic zonobiome of Magdalena River Valley Western slope Eastern cordillera

UA 3054, Orobiome with Andean and high Andean of Andalucia in the Eastern Cordillera

UA_3023, Paramo of Miraflores

UA_3013, Paramo of Frontino - Urrao

UA 3004, Paramo of Cerro Plateado

UA_3145, Orobiome with sub-Andean eastern forest of the Eastern of Putumayo

UA_3078, Orobiome with sub-Andean forest of the eastern moist forest

UA_3050, Orobiome with sub-Andean slope forest of the Western corillera

UA_3097, Orobiome with Andean and high Andean eastern forest of Caqueta

UA_3057, Orobiome with Andean and high Andean forest of upper Magdalena

UA_3043, Orobiome with Andean and high Andean forest of the Central Cordillera

UA_3059, Orobiome with sub-Andean forest easter cordillera in Andalucia

UA_3103, Humid Zonobiome with forest of Catatumbo

UA_3123, Sub-xerophytic zonobiome of Magdalena River Valley in Nechí

UA_3092, Sub-xerophytic zonobiome of Perija

UA_3014, Paramo of Guanacas - Puracé - Coconucos

UA_3099, Orobiome with sub-Andean forest eastern slope of the Eastern cordillera in Caqueta

UA_3143, Orobiome with sub-Andean forest Pacific of Patia slope in the western cordillera

UA_3139, Orobiome with sub-Andean forestof the upper Patia in the Central cordillera

UA_3147, Orobiome with sub-Andean southeast forest of Saldaña in the Central cordillera

UA_3119, Humid orobiome with Andean forest of the moist forest of the Northern of the middle Magdalena of the Eastern cordillera

UA_3058, Orobiome with Andean and high Andean forest on the western slope of the Eastern Cordillera

UA_3074, Orobiome with Andean and high Andean forest of Cauca and Valle western slope of the Western Cordillera

UA_3104, Orobiome with Andean and high Andean forest in the Canyon of Patia

UA_3071, Orobiome with Andean and high Andean forest in the high Nechi of the Central Cordillera

UA_3051, Sub-xerophytic zonobiome of the upper Cauca

UA_3033, Paramo of Tatamá

UA 3011, Paramo of El Duende

UA 3003, Paramo of Belmira

UA_3091, Orobiome with sub-Andean forest in Sinu - San Jorge

UA_3081, Orobiome with sub-Andean forest in Murri of the Western cordilllera

UA_3072, Orobiome with sub-Andean eastern forest of the upper Nechi Central cordillera

UA_3034, Paramo of Tota - Bijagual - Mamapacha

UA_3032, Paramo of Tamá

UA_3019, Paramo of the Cocha - Patascoy

UA_3076, Orobiome with sub-Andean forest Pacific - Cauca slope of the western cordillera

UA_3106, Orobiome with sub-Andean forest in Quindio - Antioquia en the Canyon of Cauca

UA_3036, Orobiome with Andean and high Andean forest with eastern moist forest of the Eastern Cordillera

UA_3113, Orobiome with Andean and high Andean forest in the Magdalena Medio of the Central Cordillera

UA_3132, Dry Zonobiome in San Lucas

UA_2027, Sub-xerophytic zonobiome of upper Patia River Valley

UA_3035, Paramo of Yariguíes

UA_3140, Orobiome with sub-Andean forest of Patia

UA_3117, Orobiome with sub-Andean forest of the western moist forest of the middle Magdalena in the Eastern Cordillera

UA_3118, Orobiome with sub-Andean eastern forest of the Central cordillera

UA_3112, Halobiome of the Magdalena in Lebrija 


\section{Andes (cont.)}

UA_3069, Sub-xerophytic zonobiome Western slope of the Eastern cordillera in the upper Magdalena

UA_3108, Sub-xerophytic zonobiome in the Cauca Canyon

UA_3020, Paramo of the Hermosas

UA_3007, Paramo of Chingaza

UA_3137, Orobiome with sub-Andean forest of the upper Patia

UA 3063. Orobiome with sub-Andean forest in San Angustin - Central cordillera

UA 3144, Orobiome with Andean and high Andean forest eastern slope in Nariño - Putumayo

UA_3045, Orobiome with Andean and high Andean eastern forest of the high and middle Cauca in the Eastern Cordillera

UA_3041, Halobiome of the Plain of the upper Cauca

UA_3082, Orobiome with sub-Andean northwest forest of the Eastern cordillera of lower Atrato

UA_3126, Humid Zonobiome of the Magdalena in Nechi

UA_3129, Humid Zonobiome of the river valley of Magdalena in Nechi

UA_3018, Paramo of Jurisdicciones - Santurban - Berlin

UA 3012, Paramo of Farallones de Cali

UA_3098, Orobiome with sub-Andean eastern forest of Caqueta

UA_3141, Orobiome with sub-Andean forest in Awa territory

UA_3040, Humid orobiome with Andean forest of tha Macarena

UA_3095, Orobiome with Andean and high Andean forest of the Caqueta

UA_3077, Orobiome with Andean and high Andean eastern forest of Meta of the Eastern Cordillera

UA_3149, Orobiome with Andean and high Andean forest in the San Juan slope in the Western Cordillera

UA_3158, Halobiome of the Middle Magdalena

UA 3124, Humid Zonobiome of the moist forest in the North of the Eastern cordillera

UA_3127, Humid Zonobiome of the river valley of Magdalena in Carare

UA_3052, Humid Zonobiome of the canyon valley of Cauca river

UA_3066, Sub-xerophytic zonobiome of Magdalena River Valley in San Agustín

UA_3027, Paramo of Pisba

UA 3024, Paramo of Nevado of Huila

UA_3009, Paramo of Cruz Verde - Sumapaz

UA_3005, Paramo of Chiles - Cumbal

UA_3154, Orobiome with sub-Andean forest of the western moist forest of the Eastern Cordillera

UA 3047, Orobiome with sub-Andean forest of the Eastern Slope of the Western Cordillera

UA_3073, Azonal Orobiome with sub-andean forestof the Canyon of Dagua

UA_3037, Orobiome with Andean and high Andean eastern forest of the Central Cordillera

UA_3146, Orobiome with Andean and high Andean forest in the Saldaña

UA_3116, Orobiome with sub-Andean forest of the moist forest of the middle Magdalena to the North of the Eastern Cordillera

UA_3138, Orobiome with sub-Andean forest of the upper Patia Western cordillera

UA_3107, Orobiome with sub-Andean eastern forest of the Eastern cordillera

UA_3156, Humid orobiome with Andean forest in the Western slope of the Easter cordillera

UA_3096, Orobiome with Andean and high Andean forest of Huila and Caqueta eastern slope of the Eastern Cordillera

UA_3093, Humid Zonobiome of the Magdalena of the Serrania of San Lucas

UA_3125, Humid Zonobiome of the western moist forest in the Eastern cordillera

UA_3053, Sub-xerophytic zonobiome of the Cauca river

UA_3157, Andean sub-xerophytic pedo-zonobiome of Canyon of Patia

UA_3026, Paramo of Perijá

UA_3016, Paramo of Guerrero

UA 3015, Paramo of Guantiva - La Rusia

UA_3090, Orobiome with sub-Andean forest of Perija

UA_3155, Humid orobiome with Andean forest of the moist forest of the Northern of the East cordillera

UA_3102, Humid orobiome with Andean forest of the Catatumbo Montains

UA_3080, Orobiome with Andean and high Andean northwest forest of the Western Cordillera

UA_3110, Humid Zonobiome Valley in the canyon of Cauca

UA_3017, Paramo of Iguaque - Merchan

UA_3008, Paramo of Citara

UA_3133, Orobiome with Andean and high Andean forest of Patia

UA_3029, Paramo of Sierra Nevada of Cocuy 
Andes (cont.)

UA_3006, Paramo of Chili - Barragan

UA_3038, Orobiome with sub-Andean eastern forest of the Eastern cordillera

UA_3064, Orobiome with sub-Andean southeast forest of upper Magdalena in the Central cordillera

UA 3048, Orobiome with sub-Andean forest of Cauca and Valle in the Central cordillera

UA_3089, Orobiome with Andean and high Andean forest in Perija

UA_3114, Orobiome with Andean and high Andean forest western slope of the Western Cordillera of middle Magdalena

UA 3134, Orobiome with Andean and high Andean forest in the high Patia

UA_3094, Humid Zonobiome of the river valley of Magdalena in Perija south of lowest Magdalena

UA 3148, Sub-xerophytic zonobiome of Magdalena River Valley in the Saldaña

UA_3021, Paramo of the Nevados

UA_3002, Paramo of Cundiboyacense

UA_3001, Paramo of Almorzadero

UA_3060, Orobiome with sub-Andean forest of the western moist forest of the upper Magdalena in the eastern Cordillera

UA 3039, Humid orobiome with Andean forest of the Macarena

UA_3075, Orobiome with Andean and high Andean eastern forest of Dagua

UA_ 3109, Humid Zonobiome of the river valley in Sinu - San Jorge

UA_3031, Paramo of Sotará

UA_3028, Paramo of Rabanal y río Bogot $\square$

UA_3122, Orobiome with sub-Andean forest in Nechi

UA_3121, Orobiome with sub-Andean forest of the upper Nechi

UA_3153, Orobiome with sub-Andean forest of the moist forest of the North of the Eastern Cordillera

UA_3049, Orobiome with sub-Andean forest of Quindio and Antioquia in the Central cordillera

UA_3136, Orobiome with Andean and high Andean forest western slope in Nariño

UA 3055, Orobiome with Andean and high Andean forest of the high Magdalena in the Eastern Cordillera

UA_3105, Orobiome with Andean and high Andean eastern forest of the Cauca Canyon of the Eastern Cordillera

\section{Orinoquia}

UA_4004, Halobiome with gallery forest in the Ariari - Guayabero

UA_4007, Humid Zonobiome in the Arari - Guayabero

UA_4005, Pedo-Zonobiome sub-xerophytic with savanna in the Macarena

UA_4012, Halobiome of the Piedmont Meta

UA 4014, Pedo-Zonobiome sub-xerophytic of Arauca - Apure

UA_4009, Halobiome of the Arauca - Apure

UA_4013, Pedo-Zonobiome sub-xerophytic with savanna in Meta piedmont

UA_4003, Halobiome with gallery forest with jungle of the North of Guaviare

UA 4006, Humid Pedo-Zonobiome in High Savanna

UA_4010, Halobiome of Casanare

UA_4015, Humid Pedo-Zonobiome of Casanare

UA_4017, Humid Zonobiome in Meta Piedmont

UA_4002, Halobiome with gallery forest in high Savanna

UA_4008, Humid Zonobiome in the north of Guaviare

UA_4011, Halobiome of the Piedmont Casanare - Arauca

UA_4016, Humid Zonobiome in the Casanare Piedmont

Amazon piedmont

UA_5010, Halobiome of the Amazon in the San Miguel

UA_5014, Humid Zonobiome of the Amazon piedmont in San Miguel

UA 5007, Humid Zonobiome of the Amazon piedmont in Caguán

UA_5001, Halobiome of the Amazon of the middle Caqueta

UA 5006, Humid Zonobiome of the Amazon in Florencia

UA_5012, Humid Zonobiome of the Amazon in San Miguel

UA 5003, Halobiome of the Amazon in Florencia

UA_5013, Humid Zonobiome of the Amazon piedmont in Putumayo

UA 5002, Halobiome of the Amazon of the Caguan

Amazon piedmont (cont.)

UA_5011, Humid Zonobiome of the Amazon in the Putumayo

UA 5008, Humid Zonobiome of the Amazon piedmont in Florencia

UA_5004, Humid Zonobiome of the Amazon in the Caguan

UA_5005, Humid Zonobiome of the Amazon in the middle Caqueta

UA 5009, Halobiome of the Amazon in the Putumayo 
Scientific Research Publishing (SCIRP) is one of the largest Open Access journal publishers. It is currently publishing more than 200 open access, online, peer-reviewed journals covering a wide range of academic disciplines. SCIRP serves the worldwide academic communities and contributes to the progress and application of science with its publication.

Other selected journals from SCIRP are listed as below. Submit your manuscript to us via either submit@scirp.org or Online Submission Portal.
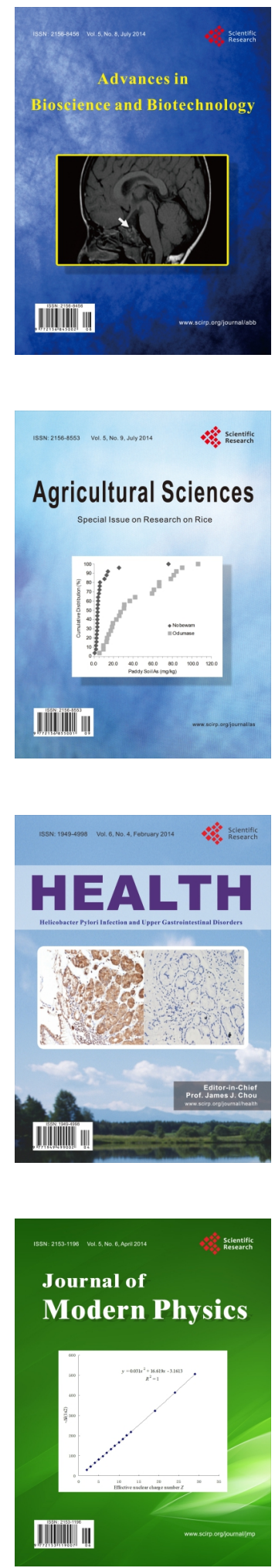
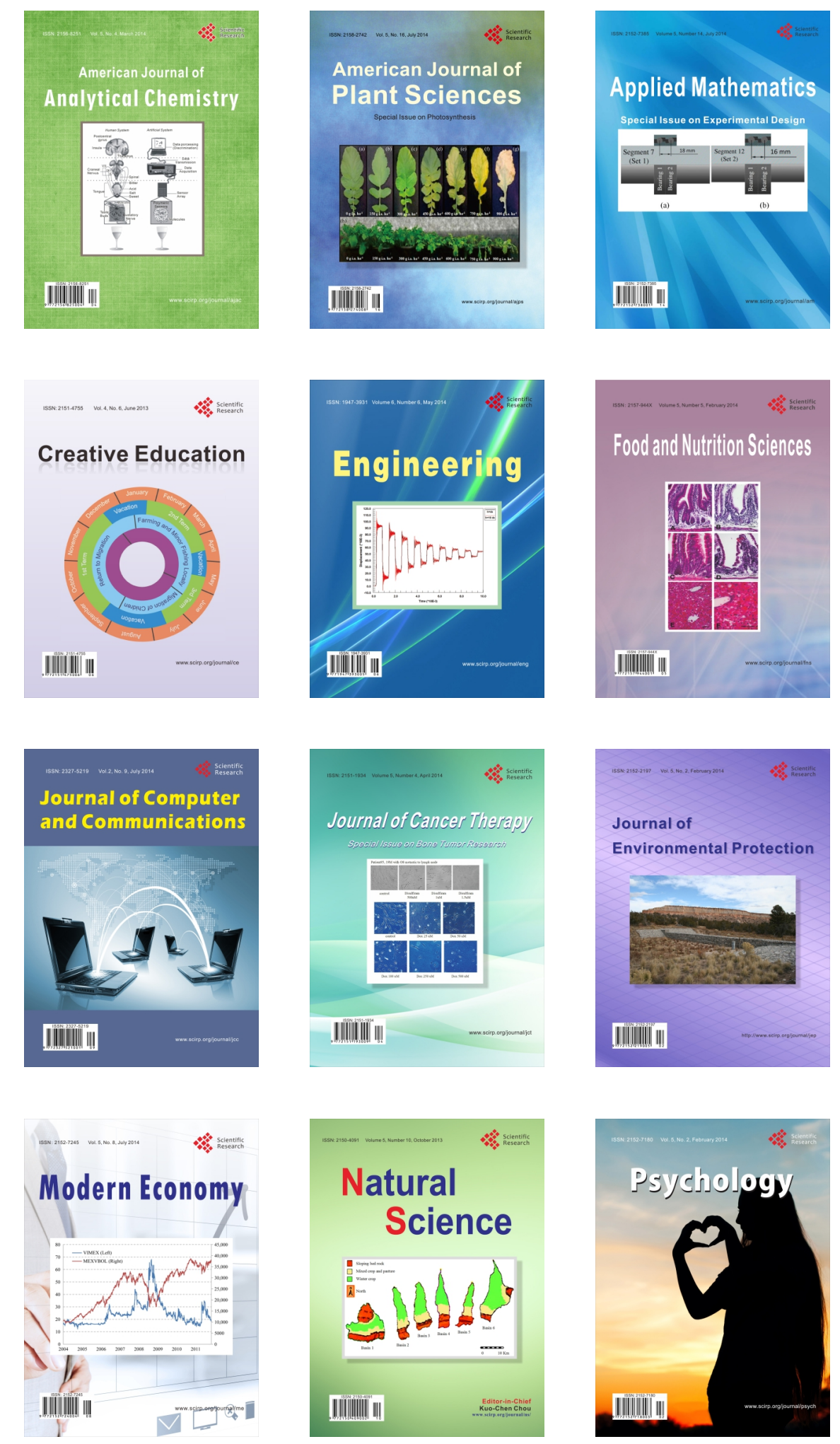